\title{
Çocukluk Çağında Obezitenin Öncülleri Hakkında Bir Derleme
}

\author{
Hatice Melis Müren ${ }^{1}$ \\ MEF Üniversitesi
}

\author{
Hatice Şule Yasin ${ }^{2}$ \\ Bilgi Üniversitesi
}

\begin{abstract}
Özet
Okul öncesi dönem ve çocukluk döneminde yüksek tartıl1lık ve obezite dünya genelinde bir sağlık sorunu haline gelmiştir. Dünya Sağlık Örgütü'nün (2020) raporuna göre 1975 ve 2016 yılları arasında dünya çapında çocuklardaki obezite yaygınlığ 3 katına çıkmış, 2016 yılında 5 yaşın altındaki 41 milyondan fazla çocukta yüksek tartılılık ve obezite görüldüğü tespit edilmiştir. Obezitenin çok çeşitli sağlık sorunları ile ilişkilendirildiği ve son yıllardaki aşırı artı̧̧ göz önüne alındığında, obezitenin öncüllerinin belirlenmesi ve bunlara yönelik müdahale programlarının geliştirilmesi büyük önem taşımaktadır. Mevcut derlemenin amacı, okul öncesi dönemde çocuklarda obezite oluşumuna etki eden çocuk besleme davranışları, ebeveynlik stilleri, anne bilişleri ve çocukların mizaç özellikleri ile ilgili ulusal ve uluslararası yazında yapılmış araştırmaları derlemek ve konuyla ilgili Türkiye'de yapılacak araştırmalar ve müdahale çalışmaları için zemin hazırlamaktır. Alan yazındaki sonuçlar genel olarak kısıtlayıcı besleme, otoriter ebeveynlik, annelerin çocukların kilosu hakkındaki yanlış algıları ve olumsuz duygulanımı yüksek çocuk mizacının obezitenin muhtemel öncülleri olabileceğini ortaya koymuş, erken yaşta obezite riskinin önüne geçmek için ebeveynlerin obezite farkındalığını artırmaya ve ebeveynlik davranışlarına yönelik müdahale programlarının önemine vurgu yapmıştır. Obezitenin öncüllerinin daha iyi anlaşılabilmesi ve uygun müdahale programlarının geliştirilebilmesi için daha fazla araştırmaya ihtiyaç vardır.
\end{abstract}

Anahtar kelimeler: Obezite, besleme davranışları, ebeveynlik stilleri, anne bilişleri, çocuk mizacı

\section{Abstract}

Overweight/obesity in childhood has become a worldwide health problem. World Health Organization (2018) reported that the prevalence of obesity in children worldwide tripled between 1975 and 2016 with more than 41 million children before age 5 were overweight/obese in 2016. Given that obesity has been associated with a wide range of physiological and psychological problems and its excessive increase in recent years, it is highly important to identify the precursors of obesity and develop intervention programs targeting them. The present review compiles national and international research regarding child feeding behaviors, parenting styles, maternal perceptions and child temperament as important precursors of obesity in early childhood and aims to facilitate further research and obesity intervention programs in Turkey by giving a thorough summary of literature about the subject. Results in the literature suggested that parental restrictive feeding, authoritarian parenting style, inaccurate maternal perceptions of child weight and high negative affectivity as a temperamental trait in children may all be potential risk factors for childhood obesity. The need for intervention programs targeting parenting behaviors and parental awareness of overweight is emphasized. Further longitudinal studies are required to uncover the precursors of obesity and develop appropriate intervention programs.

Keywords: Obesity, child feeding behaviors, parenting styles, maternal perceptions, child temperament

Yazışma Adresi: 'Dr. Öğr. Üyesi, Hatice Melis Müren, MEF Üniversitesi, İktisadi İdari ve Sosyal Bilimler Fakültesi, Psikoloji Bölümü, Maslak, Sarıer / İstanbul, murenm@mef.edu.tr, ORC-ID: 0000-0002-2780-1962

${ }^{2}$ Hatice Şule Yasin, Bilgi Üniversitesi, Eyüpsultan / İstanbul, ORC-ID: 0000-0001-7343-9549

Gönderim Tarihi: 29.01 .2020

Kabul Tarihi: 04.08 .2021 
Obezite son dönemde hem yetişkinlik çağında hem de çocukluk çağında yaygınlığ 1 hızla artmakta olan bir sağlık problemidir (Dai ve ark., 2020). Dünya Sağlık Örgütü (DSÖ; World Health Organization; WHO, 2020) tanımına göre obezite kişilerin boy ve kilo oranları ile hesaplanan beden kitle indeksi değerleri ile belirlenmekte olup; yetişkinlik çağında beden kitle indeksi 25 üzerinde olan bireyler yüksek tartılı (obez öncesi; overweight), 30 ve üzerinde olan bireyler ise obez olarak değerlendirilmektedir. Çocukluk çağında ise obezite ve yüksek tartılı olma kriterleri, çocukların yaş ve cinsiyetine göre belirlenmektedir (WHO, 2020). Obezite genellikle yetişkinlik çağ1 sorunu olarak düşünülmektedir, fakat bulgular okul öncesi dönem ve çocukluk döneminde de yüksek tartılılık ve obezitenin dünya çapında bir sağlık sorunu haline geldiğini göstermiştir (bk. Wang ve Lobstein, 2006; Weichrauch-Blüher ve Wiegand, 2018). Dünya Sağlık Örgütü'nün raporuna göre 1975 ve 2016 yılları arasında dünya çapında çocuklardaki obezite yaygınlığ 3 katına çıkmış, 2016 yılında 5 yaşın altındaki 41 milyondan fazla çocukta yüksek tartıl1lık ve obezite görüldügü tespit edilmiştir (WHO; 2020). Bu artış endişe vericidir, çünkü erken yaşta başlayan obezite yetişkinlik çağında da kalıcı olabilmektedir (Magarey ve ark., 2003; Reilly ve ark., 2003). Ek olarak obezitenin hem eș zamanlı hem de boylamsal olarak olumsuz fizyolojik (ör. düşük ortalama yaşam süresi, yüksek koroner kalp hastalığı riski) ve psikolojik (ör. yüksek anksiyete, depresyon, davranış problemleri vb.) sonuçlar doğurabildiği bilinmektedir (Eschenbeck ve ark., 2009; Maiano ve ark., 2018; Reilly ve Kelly, 2011; Storch ve ark., 2007). $\mathrm{Bu}$ nedenlerle çocukluk çağındaki obezitenin öncüllerinin belirlenmesi önemlidir.

Araştırmalar, Türkiye'de de obezite artışının endişe verici olduğunu göstermektedir. Örneğin bulgular, 1990-1995 yıllarından 2011-2015 yıllarına dek 5-19 yaş aralığındaki çocuk ve ergenlerde obezite yaygınlığının $\% 0.6$ 'dan \%7.3'e yükseldiğini göstermiştir (Alper ve ark., 2018). Ayrıca, 5 yaşın altındaki çocuklarda obezite görülme sıklığ1 \%8.5, yüksek tartılılık ise \% 17.9 gibi oldukça yüksek oranlara sahiptir (Türkiye Beslenme ve Sağlık Araştırması, 2014). Bu bulguları destekler nitelikte, 2016-2017 eğitim öğretim yılında gerçekleştirilen Türkiye Çocukluk Çağı Şişmanlık Araştırması'nın verilerinde de 7-8 yaş aralığındaki çocukların \%14,6'sının fazla kilolu, \%9,9'unun ise obez olduğu tespit edilmiştir (COSITUR, 2016). Sonuç olarak bu bulgular, okul öncesi ve çocukluk döneminde obezitenin Türkiye'de de büyük bir sorun haline gelmekte olduğunu göstermektedir. Obezitenin çok çeşitli sağlık sorunları ile ilişkilendirildiği ve son yıllardaki aşırı artışı göz önüne alındığında obeziteye yönelik özellikle çocukluk çağını hedefleyen müdahale programlarının geliştirilmesi çok kritiktir. $\mathrm{Bu}$ müdahale çalışmalarının hedeflerinin doğru belirlenebilmesi için de obezitenin öncüllerinin ortaya çıkarılması büyük önem taşımaktadır.

Obezite Türkiye'de genellikle ilköğretim çağındaki çocuklar, ergenler ve erişkinlerden oluşan örneklemlerle araştırılmıştır (ör. Öztürk ve Aktürk, 2011; Turan ve ark., 2007; Uzun, 2015). Fakat okul öncesi dönem, obezite probleminin oluşumu için çok önemli olmasına rağmen Türkiye'de okul öncesi çocuklarda obezite ile ilgili yapılan araştırmaların sayısı kısıtlıdır. Ayrıca, obeziteyle ilişki içinde araştırılmış olan konular çoğunlukla biyolojik faktörler, beslenme alışkanlıkları ve fiziksel aktivitedir (Aksakal ve Oğuzöncül, 2017; Öztora ve ark., 2006; Yücel ve ark., 2011). Tüm bu faktörler obezite gelişimi için çok kritik olmakla birlikte, hem erişkinler hem de çocuklar için obezite ile ilişkili psikolojik faktörler çok fazla araştırılmamıştır. Dolayısıyla obezite, Türkiye'de çoğunlukla sağlık çalışanları tarafindan ve ergenler, erişkinler ve okul çağındaki çocuklardan oluşan örneklemlerle araştırılmakta olan bir konudur. Fakat alan yazındaki, çoğunlukla Batılı kültürlerde gerçekleştirilmiş mevcut çalışmalar çocukların yeme alışkanlıklarının obezite riskinde önemli payı olduğunu ve bu alışkanlıkların genel olarak okul öncesi dönemde aile etkisi ile belirlendiğini göstermiştir (Olvera-Ezzell ve ark., 1990; Patrick ve Nicklas, 2005; Scaglioni ve ark., 2008; Gahagan, 2012). Araştırmacılar, ebeveynlerin çocuk besleme davranışlarının çocuklarda obezite oluşumunu tetikleyen önemli etkenlerden biri olduğunu (Wardle ve ark., 2002) ve besleme davranışlarının çocukların tükettiği besin tipi, miktarı, yeme sıklığı ve beslenmenin gerçekleştiği sosyal bağlam gibi pek çok faktörü etkileyebildiğini ortaya koymuştur (Birch ve Davison, 2001). Daha az araştırılmış olan fakat obezite ile ve çocukların yeme davranışları ve annelerin yedirme davranışları ile ilişkili olan faktörler ise ebeveynlik bilişleri ve stilleri (Ventura ve Birch, 2008) ve çocukların mizaç özellikleridir (Bergmeier ve ark., 2014). Bronfenbrenner' in (1989) Bio-Ekolojik Sistemler Modeli, çocuklardaki çıktıların farklı sistemler ile doğrudan veya dolaylı olarak etkileşim içinde olduğunu belirlemiştir. Modele göre gelişimsel çıktılara tüm sistemler etki etmektedir ve farklı sistemlerin etkisi bütüncül bir şekilde araştırılmalıdır (Bronfenbrenner, 1986). Bu teorik model 1şı̆̆ında mevcut derlemenin amac1, çocuğun bireysel özellikleri ve ebeveynlerin biliş ve davranışlarının, kültürel bağlam da gözetilerek, obezite gelişimine olan etkisine 1şık tutmaktır. Ayrıca derlemenin hedefi Türkiye'de görece az araştırılmış olan ve okul öncesi dönemde çocuklarda obezite oluşumuna etki eden çocuk besleme davranışları, ebeveynlik stilleri-bilişleri ve çocukların mizaç özellikleri gibi etkenlere dikkat çekmek, ulusal ve uluslararası yazında yapılmış ilgili araştırmaları derlemek ve konuyla ilgili Türkiye'de ya- 
pılacak araştırmalar ve müdahale çalışmaları için zemin hazırlamaktır. Bu bağlamda, mevcut derlemede obezitenin önemli öncülleri olan ebeveynliğin farklı boyutları ve çocuk mizaç özellikleri ulusal ve uluslararası bulgular çerçevesinde değerlendirilmiştir.

\section{Ebeveynlerin Çocuk Besleme Davranışları ve Obezite}

Ebeveynlerin davranışlarının çocuklarının yeme davranışlarını, yiyecek seçimlerini ve tüketimlerini şekillendirmede etkili olduğu pek çok araştırma tarafindan gösterilmiştir (ör. Golan ve Crow, 2004). Özellikle ebeveynlerin çocuklarını beslemeye yönelik davranış ve tutumları, çocukların yeme davranışlarını belirlemede önemli rol oynamaktadır (Birch ve Fisher, 1998). Çocuk besleme davranışları, ailelerin çocuklarına yemek yedirirken kullandıkları davranışları içerir. Yapılan pek çok çalışma ebeveynlerin çocuk besleme davranışları ile çocukların beden kitle indeksi arasında önemli bir ilişki olduğunu ortaya koymuştur (Hughes ve ark., 2005; Rhee ve ark., 2006; Savage ve ark., 2007; Yavuz ve Selçuk, 2018).

Çocukların yeme davranışları, yeme bağlamında gösterilen çocuğun açlık hissine duyarlı olma, zamanında ve çocuğun gelişimsel ihtiyaçları gözetilerek besleme gibi duyarlı ebeveynlik davranışlarından (Black ve Aboud, 2011), ebeveynlerin sağlıklı beslenme konusunda çocuklara rol model olmasından ve çocukların yenilecek yemeklerin seçimi ve hazırlanması gibi aşamalara dahil edilmesinden (Russel ve ark., 2015) ve genel olarak ebeveyn-çocuk arasındaki güvenli bağlanma ilişkisinden (Anderson ve Whitaker, 2011) olumlu yönde etkilenebilmektedir. Evde gıda çeşitliliği ve dengesini sağlamak, sağlıklı beslenmeyi destekleyen bir ev ortamı yaratmak ve çocuklara sağlıklı beslenme hakkında bilgi vermek gibi ebeveynler tarafından gösterilen beslenmeye dair olumlu davranışlar, çocuklarda daha az yemek seçiciliği ve yemekten daha fazla keyif alma ile ilişkilendirilmiştir (ör. Holley ve ark., 2020). Fakat alan yazında ebeveynlerin çocuk besleme davranışları sıklıkla 3 temel davranış çerçevesinde (bk. yeme için bask1, kısıtlama, takip etme) çalışılmıştır (Birch ve ark., 2001). Bu nedenle mevcut derlemede ebeveynlerin besleme davranışları bu 3 temel davranış bağlamında ele alınarak tartışılmıştır.

Ebeveynlerin sıklıkla gösterdiği besleme davranışlarından ilki, çocuğa yemek yemesi için baskı uygulamaktır (pressure to eat), ve bu davranış çocuğu tabağındaki yemeği bitirmesi veya belli besinleri tüketmesi için zorlama gibi davranışları içerir (Birch ve ark., 2001). İkincisi, çocuğun yediklerini kısıtlama (restriction) davranışıdır. Çocuğun belli besinleri tüketmesini engellemek anlamına gelir (Birch ve ark., 2001). Kisitlama davranışı açık (overt restriction) ve örtük (covert restriction) kısıtlama olmak üzere iki şekilde gerçekleştirilebi- lir (Ogden ve ark., 2006). Ogden ve arkadaşlarına (2006) göre açık kısıtlama, ebeveynin çocuğunun belli bir yiyeceği yemesine izin vermemesi ve bunu çocuğun fark edebileceği biçimde (ör. sözle veya önünden yiyeceği alarak) yapmasını ifade eder. Örtük kısıtlama davranışı ise ebeveynler tarafindan çocukların daha az fark edebileceği şekillerde gerçekleştirilir. Ebeveynin çocuğun yemesini istemediği besinleri satın almaması, evde bulundurmaması, markette çocuğun tüketmesini istemediği yiyeceklerin satıldığ 1 koridorlara çocuk ile beraberken girmemesi örtük kısıtlama davranışlarına örnek olarak gösterilebilir (Ogden ve ark., 2006). Üçüncü davranış ise çocuğun yediklerini takip etmektir (monitoring) ve çocuğun nerede, ne zaman, ne kadar ve ne yediğinden haberdar olmak anlamına gelir (Birch ve ark., 2001). Bahsedildiği gibi, tüm bu davranışlar çeşitli çalışmalarca çocukluk çağındaki ve sonraki dönemlerdeki beden kitle indeksi ve obezite riski ile ilişkili bulunmuştur (Faith ve ark., 2004b; Rodgers ve ark., 2013). Aşağıda, sözü edilen besleme davranışları ve bu davranışların sonuçları alan yazındaki bulgular bağlamında değerlendirilmiştir.

\section{Yemek için Baskı}

Yemek için baskı uygulamak, ebeveynler tarafindan genellikle çocukların yeterli besin tükettiğinden emin olmak ve sağlıklı gelişimlerine olanak tanıyacak yiyecekleri daha çok tüketmelerini sağlamak amacıyla gösterilen bir davranıştır (Birch ve ark., 2001). Okul öncesi dönem ve okul çağındaki çocuklarla yapılan farklı araştırmalar bu yargıyı destekler nitelikte, annelerin yeme için baskı uygulama davranışının çocuklarda daha düşük beden kitle indeksi ile ilişkili olduğunu tespit etmiştir (bk. Birch ve ark., 2001; Blisset ve Haycraft, 2008; Hurley ve ark., 2011; Shloim ve ark., 2015). Bu bulgular farklı demografik özelliklere sahip ailelerde de (örneğin, düşük gelirli ve Afrika kökenli Amerikalı aileler) tekrarlanmıştır (Powers ve ark., 2006).

Batılı örneklemler ile gerçekleştirilmiş çalışmaların yanında, Türkiye'de annelerin besleme davranışları ile çocuklardaki obezite/yüksek tartılılık gelişimi arasındaki ilişkileri inceleyen çalışmalar, sınırlı sayıda da olsa, mevcuttur ve bulgular batılı örneklemle gerçekleştirilmiş çalışmaların bulguları ile uyum göstermektedir (ör. Camcı ve ark., 2018). Ülkemizde, okul öncesi ve okul çağı çocukları ve aileleri ile gerçekleştirilen çalışmalar yemek için baskı uygulamanın çocuklarda düşük beden kitle indeksi ile ilişkili olduğunu göstermiştir (Camc1 ve ark., 2018; Yavuz ve Selçuk, 2018). Farklı sosyoekonomik düzeylere sahip 6-10 yaş aralığındaki çocuklar ve ebeveynleriyle gerçekleştirilmiş bir diğer çalışmada da yemek için baskı uygulama davranışının en çok zayıf çocukların ebeveynlerinde ve en az yüksek tartılı/obez çocukların ebeveynlerinde görüldüğü tespit edilmiş, 
dolayısıyla beden kitle indeksi ve yeme için baskı arasındaki olumsuz yöndeki iliş̧i burada da yinelenmiş̧ir (Erdem ve ark., 2017).

Özetle pek çok araştırma yeme için baskı uygulama ile çocuklarda düşük beden kitle indeksi arasında olumlu yönde bir ilişki göstermektedir, ancak alan yazında bu ilişkinin etki mekanizmaları ile ilgili ortak bir çıkarımın mevcut olmadığı görülmektedir. Örneğin, bazı boylamsal çalışmalar çocuklara sağlıklı yiyecekler tüketmeleri için baskı yapmanın uzun vadede çocuklarda daha fazla liffli gıda ve daha az şeker tüketimi ile ilişkili olduğunu gösterirken (Gubbels ve ark., 2011), bazıları ise yemeleri için baskı uygulanan çocukların besin seçiciliğinin zaman içinde artabildiğini gözlemlemiştir (Jansen ve ark., 2017). Ülkemizde okul öncesi dönemde çocuğu olan annelerle yapılan bir araştırma ise, anneleri tarafindan yemeleri konusunda baskı gören çocukların besinden keyif almalarının daha az; besin seçiciliği, tokluk heveslisi olma (sadece doymak için yeme) ve yavaş yeme davranışlarının ise daha fazla olduğunu göstermiştir (Özdoğan ve ark., 2018). Bu bulgular bir arada değerlendirildiğinde yemek için baskı uygulamanın çocuklarda sağlıklı yiyecek seçimini desteklemesi mümkünken, çocuklarda yeme isteğinin ve yemekten alınan keyfin azalmasının da olası çıktılar arasında olduğu görülmektedir.

Çelişkili görünen bu bulguları kuramsal olarak farklı şekillerde açıklamak mümkündür. İlk olarak, çocuklara yemek yemeleri için baskı uygulamak yemekle ilgili olumsuz tutumlara ve çocukların tüm besinleri tüketiminin azalmasına sebep olabilmekte (ör. Özdoğan ve ark., 2018), buna bağlı olarak da bask1 uygulanan çocuklarda yemek yeme oranı, dolayısıyla da yüksek tartıl1lık ve obezite görülme riski azalabilmektedir (bk. Loth, 2016). Bu kuramsal bağlamı destekler şekilde, yemeleri için baskı uygulandığında okul öncesi çağdaki çocukların daha az besin tükettikleri ve yiyeceklerle ilgili çok daha fazla olumsuz yorumda bulundukları gözlenmiştir (Galloway ve ark., 2006). Benzer bir etki yetişkinlik yıllarında da gözlemlenmiş, üniversite öğrencileriyle yapılan geriye dönük bir araştırmada anneleri tarafindan belirli bir yiyeceği yemesi için baskı yapılan öğrencilerin bu yiyeceği yetişkinlikte de tüketmeyi tercih etmedikleri belirlenmiştir (Batsell ve ark., 2002). Dolayısıyla çocukluk çağında maruz kalınan yeme için baskı, hem çocukluk çağında hem de sonrasında kişilerin baskı gördükleri yiyeceği tüketme isteğini ve miktarını azaltabilmektedir. $\mathrm{Bu}$ açıdan değerlendirildiğinde, baskı gören çocukların genel olarak daha az besin tükettikleri ve dolayısıyla daha düşük beden kitle indeksine sahip oldukları düşünülebilir.

Mümkün olan bir başka açılama ise sağlıklı besinler yemesi için baskı uygulanan çocukların bu besinleri daha fazla tüketerek sağlıklı kiloda kaldıklarıdır. Bunu destekler şekilde bazı çalışmalar yeme için baskının sağlıklı yiyeceklerin tüketimi ile ilişkili olduğunu, yemeleri için baskı gördüklerinde çocukların daha fazla sağlıklı yiyecek tüketebildiğini göstermiştir (ör. Bourcier ve ark., 2003). Fakat bu bulgu her zaman desteklenmemiştir ve bazı çalışmalar tam tersi etki önermiş, yeme için baskı gören çocukların daha fazla sağlıksız atıştırmalıklar ve yüksek derecede yağ içeren besinler tükettiğini belirlemiştir (Brown ve ark., 2008; Lee ve ark., 2001). Bu bulgular bir arada değerlendirildiğinde, çocukların düşük beden kitle indeksine sahip olmalarının, her zaman sağlıklı oldukları veya sağlıklı beslendikleri anlamına gelmeyebileceği görülmektedir. Ebeveynler çocuklarına genellikle sağlıklı yiyecekleri tüketmeleri için baskı uyguladığından, yeme için baskı yapmanın sağlıklı yiyecekleri tüketme davranıșını azaltması, bunun yerine çocukların sağlıksız yiyecekleri tüketimini artırması veya genel olarak tüm besinlerin tüketimini azaltması da ihtimaller arasındadır. Başka bir deyişle baskı uygulama sonucunda tüketilen besin miktarı artmayabilir; fakat azalabilir ve/veya besleyicilik kalitesi düşebilir.

Olası başka bir açılama ise ebeveynlerin besleme davranışlarının çocukların beden kitle indeksine göre şekillenmesidir (Jansen ve ark., 2014; Webber ve ark., 2010). Buna göre düşük kiloda ve yemeye isteksiz çocukların ebeveynlerinin, çocuklarına yemek yemeleri için daha çok baskı uyguluyor olmaları muhtemeldir. Kesitsel çalışmalar ve kısa süreli boylamsal çalışmalar bu ilişkinin yönünü net tayin etmekte kısıtlı kaldıkları için, her zaman tutarlı olmayan ve etki mekanizmaları net açıklanamayan sonuçlar elde edilmiş olması olasıdır. Sonuç olarak, yeme için baskı genellikle düşük beden kitle indeksi ile ilişkilendirilmekle birlikte, ilişkinin etki mekanizmalarının net bir şekilde belirlenemediği görülmektedir.

\section{Ktsıtlayıcı Besleme}

Anneler genellikle çocuklarının yediklerini kısıtlama davranışını çocukların sağlıksız besinler tüketmelerini en aza indirmek amacıyla gerçekleştirmektedir. Fakat, bu niyetin aksi şekilde, araştırmalar kısıtlayıcı çocuk besleme davranışlarının çocukluk çağında obezite oluşumunu tetikleyebileceğini göstermektedir (Faith ve ark., 2004b). Batılı kültürlerde, okul öncesi ve okul çağındaki çocuklarla gerçekleştirilen pek çok kesitsel çalışma, ebeveynlerin kısıtlama davranışı ile çocukların yüksek beden kitle indeksi arasında olumlu ilişki tespit etmiştir (bk. Clark ve ark., 2007; Costa ve ark., 2011; Jansen ve ark., 2012; Patrick ve Nicklas, 2005; Shloim ve ark., 2015). Benzer bulgular farklı etnik köken ve ekonomik duruma sahip ailelerde de belirlenmiştir (ör. Cardel ve ark., 2012). Okul öncesi çocuklar ve anneleriyle yapılan bir çalışmada, ebeveynlerin beden kitle indeksi, çocuk- 
ların uyku süresi ve kısıtlayıcı besleme davranışı erken yaşta obeziteyi öngören en önemli faktörler olarak gösterilmiş, tüm bu değişkenler kontrol edildiğinde, anneleri kısıtlayıcı besleme davranışı gösteren çocukların neredeyse 2 kat daha fazla obezite riski taşıdığ (Dev ve ark., 2013).

Boylamsal araştırmalar da benzer bir etki önermektedir. Bebeklik döneminden erken ergenlik dönemine kadar çok farklı yaşları kapsayan pek çok boylamsal araştırma annelerin yemeyi kısıtlayıcı davranışının çocuklarda aç olmadıkları halde yemek yeme (ör. Birch ve ark., 2003), duygusal yeme, aşırı yeme ve yemeden keyif alma (Rodgers ve ark., 2013) gibi obeziteyi arttırıc1 davranışları arttırdığını ve kısıtlayıcı beslemenin zaman içerisinde çocuklardaki beden kitle indeksinde artış ile ilişkili olduğunu göstermiştir (Hughes ve ark., 2016; Liszewska ve ark., 2018; Quah ve ark., 2019). Dolay1sıyla araştırma sonuçları, ebeveynlerin kısıtlayıcı besleme davranışının hem kesitsel hem de boylamsal olarak çocukluk çağında ve sonraki yıllarda yüksek tartılık ve obeziteyle ilişki içerisinde olduğunu ortaya koymuştur.

Bahsedildiği üzere, kısıtlayıcı besleme davranışı iki şekilde gerçekleştirilebilir. Bunlardan biri açık kısıtlama, diğeri ise örtük kısıtlama davranışıdır ve yukarıda bahsedilen araştırmalar açık kısıtlama davranışını içermektedir. Bunun yanı sıra, bazı araștırmalar örtük kısıtlama davranıșının çocukların beslenmesini olumlu etkilediği yönünde bulgulara erişmiştir (bk. Ogden ve ark., 2006). Yüksek derecede uygulanan kısıtlama davranışı çocuğun sağlıksız yiyecek tüketimiyle ilişkilendirilirken, düşük derecede ve örtük kısıtlama davranışı ise çocuğun daha fazla sağlıklı yiyecek tüketmesiyle ilişkili bulunmuştur (Boots ve ark., 2015). Dolayısıyla kısıtlama davranışları, özellikle çocuğun fark edebileceği şekilde yiyeceklerinin kısıtlanması, hem çocukluk çağında, hem de yetişkinlikte obezite için önemli bir risk faktörü olarak görülmektedir. Fakat bunun yanı sıra, çocuğun fark etmeyeceği şekilde yapılan, örtük, kısıtlama davranışlarının etkisi olumlu olabilmekte, bu davranışlar çocukların sağlıklı besinlere yönelimini artırarak obezite riskini azaltabilmektedir (Boots ve ark., 2015; 2019).

Ülkemizde gerçekleştirilen çalışmalar, kısıtlayııı besleme ve beden kitle indeksi arasında çelişkili ilişkiler göstermiştir. Örneğin, okul çağındaki çocuklarla gerçekleştirilen araştırmalarda kısıtlayıcı besleme davranışı yüksek beden kitle indeksi ile ilişkili bulunmuştur (ör. Camc1 ve ark., 2018; Cebeci ve Güven, 2014; Demir ve Bektaş, 2017). Fakat bu ilişki diğer araştırmalarca yinelenmemiştir. Örneğin, Yavuz ve Selçuk'un (2018) okul öncesi dönemdeki çocuklar ile gerçekleştirilen araştırmasında kısıtlayıcı besleme ve obezite ilişskisi, annelerin ebeveynlik stilleri kontrol edildiğinde istatistiki olarak anlamlılığını kaybetmiştir. Dolayısıyla ülkemizde yapı- lan çalışmalar net bir etki göstermemektedir; fakat çalışmaların metodolojik farklılıklarının bulguların farklı olmasının ana sebeplerinden biri olabileceği göz önünde bulundurulmalidır.

Kavramsal olarak kısıtlayıcı besleme davranışının beden kitle indeksi üzerindeki etki mekanizmalarından birinin, kısıtlayıcı besleme davranışının çocukların yeme süreçlerindeki öz denetimlerini olumsuz yönde etkileyerek kontrolsüz ve aşırı yeme davranışlarına sebep olabileceği önerilmiştir (bk. Faith ve ark. 2004b; Savage ve ark., 2007). Okul öncesi dönemdeki (3-5 yaş aras1) çocuklar ve ebeveynleri ile yürütülmüş bir çalışmada, yiyecek tüketimi konusunda daha kontrolcü olan ebeveynlerin çocuklarının kendi enerji/kalori alımlarını denetlemede daha zayıf olduğu tespit edilmiştir (Johnson ve Birch, 1994). Bu bulgular boylamsal çalıșmalarla da desteklenmiştir (ör. Birch ve ark., 2003). Çocuğun yediklerinin ebeveyn tarafından düzenli olarak kısıtlanması ve kontrol edilmesi, çocuğun kendi yediklerini düzenlemek için inisiyatif almasını engelleyebilmekte, iștahını ve neyi ne kadar yemesi gerektiğini kendi başına ve açlik/tokluk hissine güvenerek düzenleme yeteneğini köreltebilmektedir (Francis ve Susman, 2009; Golan ve Bachner-Melman, 2011; Grolnick ve Farkas, 2002). Söz konusu öz denetim güçlügü yaşamın ilerleyen yıllarında da kalıcı olabilmektedir. Çocukken kısıtlayıcı besleme davranışına maruz kalan bireyler, yedikleri üzerinde kontrol sahibi olabildikleri yetişkinlik yıllarında yeme konusunda daha az öz denetim gösterebilmekte ve obeziteyi arttırıcı besinleri (ör. yüksek yağ ve şeker oranlı yiyecekleri) daha fazla ve siklıkla tüketebilmektedirler (ör. Lev-Ari ve Zohar, 2013; Tan ve ark., 2016). Buna ek olarak araştırmalar, kısıtlama davranışının çocuklarda kisitlanan yiyeceklere duyulan isteği ve kisıtlanan yiyeceklerin tüketimini arttırabileceğini göstermektedir. Fisher ve Birch (1999a) tarafından 3-5 yaş aralığındaki çocuklar ve anneleriyle yapılan bir araştırmada, laboratuvar ortamında 10 farklı abur cubur arasından seçim yapmaları istendiğinde çocukların annelerinin kısıtladığı abur cuburları tüketmeye daha eğilimli oldukları gözlenmiştir. Aynı araştırmacılar tarafından yürütülen bir başka çalışmada, çocukların deneysel ortamda belli yiyeceklere erişimi kısıtlandığında (ör. bu yiyeceklere diğer yiyeceklerden daha kısa süre erişimleri sağland1ğında), çocukların kısıtlanan yiyeceklere daha çok ilgi gösterdikleri ve bu yiyecekleri tüketme isteklerinin daha fazla olduğu gözlemlenmiştir (Fisher ve Birch, 1999b). Genellikle ebeveynler, çocuklarının sağlıksız ve yüksek kalorili yiyecekleri tüketimini kısıtlamaktadır ve hedefleri çocuklarının bu yiyecekleri daha az miktarda tüketmesidir. Fakat bulgular, çocukların ebeveynleri tarafından kısıtlanan yiyecekleri tüketmeye daha eğilimli hale geldiklerini göstermektedir. Dahası, bu eğilim çocukluk 
çağı ile sınırlı kalmamakta, erişkinlikte de etkisini göstermektedir. Kısıtlanan yiyeceklerin genellikle sağlıksız yiyecekler olduğu düşünüldüğünde, bu bulgular kısıtlama ile yüksek beden kitle indeksi arasındaki ilişkiyi kısmen açıklar niteliktedir. Bu açıklamaya göre, çocukluk çağında kısıtlayıcı beslemeye maruz kalan çocukların, kısıtlanan ve genellikle sağlıksız olan yiyeceklere daha çok ilgi göstermesi ve yeme durumlarında öz denetimlerinin daha az olması yüksek tartılılık ve obezite problemlerinin görülme riskini artırmaktadır.

\section{Yeme Takibi}

Çocuğun yediklerini takip etmek, aldığı besinlerin çeşidinden, miktarından ve çocuğun beslenme düzeninden haberdar olmak anlamına gelir ve ebeveynler tarafından çocukların sağlıklı beslenmesi ve sağlıklı beden ağırlığını koruyabilmesi için uygulanan davranışlar arasinda yer alır (Birch ve ark., 2001). Fakat, ebeveynlerin çocuklarının yediklerini takip etme davranışına ilişkin yapılmış çoğu araştırmada, takip etme davranışı ile çocukların beden kitle indeksi arasında önemli bir ilişki tespit edilmemiştir (bk. Shloim ve ark., 2015). Ancak bazı çalışmalar, çocukların yediklerini belli düzeyde takip etmenin onların sağlıklı beslenme alışkanlıkları kazanmasında etkili olabileceğine işaret etmektedir (Faith ve ark., 2004a; Gubbels ve ark., 2011; Klesges ve ark., 1991). Örneğin, 4-7 yaş aralığındaki çocuklardan yiyecek seçmeleri istenip annelerinin seçtikleri yiyecekten haberdar olacağı söylendiğinde çocukların daha sağlıklı yiyeceklere yöneldiği gözlemlenmiştir (Klesges ve ark., 1991). Benzer şekilde boylamsal çalışmalarda anneleri tarafından yedikleri takip edilen ve sağl1klı besinler tüketmeleri için teşvik edilen çocukların daha sağlıklı bir beslenme düzenine (Faith ve ark., 2004a) ve daha düşük beden kitle indeksine (Gubbels ve ark., 2011) sahip oldukları gözlemlenmiştir.

Türkiye'de okul öncesi dönemde çocuğa sahip olan annelerin \%70'ten fazlası çocuklarının yedikleri özellikle zararlı ve sağlıksız yiyecekleri takip ettiklerini, genellikle çocukları bu yiyecekleri tükettiğinde bundan haberdar olduklarını belirtmişlerdir (Özdoğan ve ark., 2018). Bununla beraber, takip davranışı çocuklarda tokluk heveslisi olma ile olumsuz yönde ilişkilendirmiş, yani bu çocukların yemekten keyif aldıklarına ve çabuk doymadıklarına işaret edilmiştir (Özdoğan ve ark., 2018). Fakat, ülkemizde okul öncesi ve okul çağındaki çocuklar ve aileleri ile yapılan bazı araştırmalar ise annelerin takip etme davranışları ile çocukların beden kitle indeksi arasında ilişki göstermemiştir (Camcı ve ark., 2014; Yavuz ve Selçuk, 2018). Dolayısıyla, annelerin çocuklarının yediklerini takip etmesinin erken yaşta obeziteye karşı koruyucu bir faktör olması olası iken bu ilişki araştırmalar tarafından her zaman doğrulanmamıştır.

\section{Anne Bilişleri ve Çocuk Besleme Davranışları}

Annelerin besleme davranışlarının obeziteye olan etkisinin yanı sıra, annelerin besleme davranışlarına etki eden bilişleri de önceki çalışmalar tarafından incelenmiştir. Ebeveynlerin bilişleri onların çocuk ve ebeveynlik hakkındaki düşüncelerini, değerlerini, hedeflerini ve algılarını içerir ve ebeveynlik bilişlerinin ebeveynlik davranışlarının öncülleri olduğu düşünülmektedir (Yağmurlu ve Yavuz, 2012). Dolayısıyla ebeveynlerin çocuklarının yemeleri üzerine gösterdikleri davranışlarda ebeveyn bilişlerinin etkisi büyüktür. Pek çok araştırma, yeme ile ilgili bilişler ile çocuk besleme davranışları arasında ilişki göstermiştir. Örneğin, ebeveynler (çocuklarının kilolarından bağımsız şekilde) çocuklarının obez olduklarından endişe duyduklarında daha fazla kısıtlayıc1 yedirme davranışı kullanabilmekte (Francis ve ark., 2001; May ve ark., 2007), çocuklarının düşük kiloda olduklarını düşündükleri zaman ise yemek konusunda çocuklarına daha fazla baskı yapabilmektedir (Gregory ve ark., 2010). Üstelik annelerin çocuklarının kilosu hakkındaki biliş ve endişeleri, gösterdikleri kısıtlama davranışlarında çocuklarının ağırlık durumundan daha belirleyici olabilmektedir (ör. Francis ve ark., 2001). Çocuk ve ergenlerle (6-18 yaş) gerçekleştirilen bir araştırmada, çocuklarının yüksek tartılı olduğunu düşünen annelerin, çocuklarının normal kiloda olduğunu düşünenlere göre çocukları diyet yapmaya ve fiziksel aktivitede bulunmaya daha fazla teşvik ettiği gözlenmiştir (Min ve ark., 2017). Benzer şekilde, ülkemizde gerçekleştirilen bir araştırma, annelerin çocuklarını fazla kilolu olarak algıladıklarında onları daha fazla yemeye teşvik etmediklerini ve sıkıntılı oldukları durumlarda sakinleştirmek için yemek vermeyi tercih etmediklerini bulgulamıştır (Yılmaz ve ark., 2013). Okul öncesi çağdaki çocuklar ve anneleriyle gerçekleştirilen bir çalışmada ise hem çocukların gerçek kilosunun hem de annelerin çocuklarının kilosu hakkındaki algılarının, annelerin uyguladıkları besleme davranışlarıyla ilişkili olduğu, çocuklarının yüksek kiloda olduğunu düşünen annelerin özellikle yemeyi kısıtlama davranışını daha fazla gösterdikleri bulunmuştur (Hidalgo-Mendez ve ark., 2019). Bazı araştırmalarda annelerin çocuklarının yüksek tartılılığına ilişkin algıları çoğunlukla çocukların gerçek kilosuyla uyum gösterirken (ör. Min ve ark., 2017), bazılarında ise yüksek tartılı ve obez çocukları olan annelerin büyük kısmının çocuklarındaki kilo problemini fark etmedikleri belirlenmiştir (ör. Hidalgo-Mendez ve ark., 2019). Dolayısıyla annelerin davranışlarını hem bilişleri hem de objektif olarak çocukların kiloları etkileyebilmektedir. Fakat çocukların kilolarından bağımsız olarak bilişlerin etkisini gösteren çalışmalar da mevcuttur.

Tüm bu bulgular bir arada değerlendirildiğinde, çocukların kilosu hakkındaki bilişlerin annelerin gös- 
terdikleri besleme davranışlarını etkileyebileceği, ancak annelerin obezite konusunda her zaman doğru ve tarafsız bilişlere sahip olamadıkları görülmektedir. Benzer şekilde pek çok ülkede yapılan çalışmalar annelerin çocuklarındaki kilo problemini fark etmediklerini göstermektedir (Baughcum ve ark, 2000; Carnell ve ark., 2005). Anneler, okul öncesi dönemde özellikle erkek çocuklarındaki kilo problemini fark etmeyebilmekte ve çocuklarının kilolu olup olmadığını düşünmelerinden bağımsız olarak, çocuklarına yemeleri için baskı uygulayabilmektedir (ör. Chang ve ark., 2017). Ülkemizde gerçekleştirilen çalışmalar da annelerin çocuklarındaki obezite problemini fark etmediklerini, dahası çocukluk çağında tombulluğun sağlıklı olmak ile ilişkilendirildiğini ve çocukluk çağında yükssek tartılılığın anneler tarafindan bir problem olarak görülmediğini belirlemiştir (Agadayı ve ark., 2019; Peker ve ark., 2014, Savaşhan ve ark, 2015; Y1lmaz ve ark., 2013; Y1lmaz ve Osaz, 2009). Sosyal ve kültürel faktörler ebeveynlerin yüksek tart1lılık ve obezite hakkındaki algılarını, dolayısıyla çocuklarına gösterdikleri besleme davranışlarını önemli ölçüde etkileyebilmektedir (Loth ve ark., 2013; Musher-Eizenman ve ark., 2009). Dolayısıyla çocukların yedirilmesine ilişkin davranışların, davranışlara bilişlerin etkisi, bilişlere de kültürel faktörlerin etkisi gözetilerek incelenmesi yerinde olacaktır. Çocukların kiloları ile ilgili olarak olumlu algıların olması ve çocukluk çağındaki obezitenin fark edilmemesi veya olumlu olarak -sağlık göstergesi olarak- görülmesi, ebeveynlerin obezite ile ilgili olumsuz bir tutuma sahip olmamasina sebep olabilir ve annelerin besleme davranışları da buna göre şekillenebilir. Özellikle ülkemizdeki tombul çocuğun sağl1klı çocuk olduğu algısı (ör. Yılmaz ve ark., 2013) nedeniyle, ülkemizde konuyla ilgili gerçekleştirilecek çalışmalarda annelerin bilişlerinin de bir değişken olarak dikkate alınması çok önemlidir.

$\mathrm{Bu}$ bilgiler 1şığında annelerin bilişleri, çocuk besleme davranışları ve çocukların beden kitle indeksi arasındaki ilişkinin daha net olarak tespit edilebilmesi için yapılacak çalışmalara ve özellikle boylamsal incelemelere ihtiyaç olduğu görülmektedir. Ülkemizde ebeveyn besleme davranışları ve çocukların beden kitle indeksi arasındaki ilişkiyi inceleyen çalışmalar sayıca kısıtlı olduğu ve obezitenin çocukluk çağında artan bir problem olduğu göz önüne alındığında, obezitenin öncüllerinin belirleneceği çalışmalara çok ihtiyaç olduğu açıktır.

\section{Ebeveynlik Stilleri ve Obezite}

Ebeveynlik stilleri obezite ile ilişkili olan bir diğer faktördür. Ebeveynlik stilleri tanımı ebeveyn davranışlarını ve ev içerisindeki genel duygusal atmosferi kapsar ve ebeveynlerin çocuklara gösterdiği davranıș ve tutumların bütünü olarak tanımlanır (Darling ve Stein- berg, 1993; Grusec, 2002). Ebeveynlik stilleri genellikle kontrol ve sicaklık/duyarlık olmak üzere iki ebeveynlik davranış boyutu esas alınarak sınıflandırılmaktadır (Baumrind, 1978). Alan yazında yapılmış olan sınıflandırmaya göre ebeveynlik stilleri; yetkili/demokratik (authoritative) ebeveynlik, otoriter (authoritarian) ebeveynlik, izin verici/hoşgörülü (permissive) ebeveynlik ve ihmalkar (neglecting) ebeveynlik olmak üzere dört alt başlığa ayrılmıştır (Baumrind, 1978; Maccoby ve Martin, 1983). Bu derlemede bahsedilen ebeveynlik stillerinden ilk üçü (yetkili/demokratik ebeveynlik, otoriter ebeveynlik ve izin verici/hoşgörülü ebeveynlik) çocukların beden kitle indeksi ve çocukluk çağındaki obezite riski ile ilişkileri bakımından incelenmiş, hakkında pek az çalışma yapılmış olan ihmalkar ebeveynlik incelemeye dahil edilmemiştir.

Otoriter ebeveynler yüksek derecede kontrol ve olumsuz disiplin davranışlarına ek olarak düşük sıcakl1k gösteren ebeveynlerdir ve açıklama yapmaksızın katı kurallar koyma, çocuklarından sorgusuz itaat bekleme gibi davranışları sergilemeye yatkındırlar (Spera, 2005). Yetkili/demokratik ebeveynler yüksek sıcaklık gösterip ayrıca olumlu kontrol davranışları (ör. açıklayıcı disiplin) gösteren ebeveynlerdir ve bu ebeveynlik stiline sahip anne-babalar çocuklarının davranışlarına onların ilgi ve ihtiyaçlarına uygun, mantıksal olarak açıklanabilen ve anlaşılır sınırlar koymanın yanı sıra, duygusal anlamda da çocuklarına karşı sıcak ve duyarlı davranışlar gösterirler (Darling ve Steinberg, 1993). İzin verici/hoşgörülü ebeveynler yüksek sıcaklık gösterirler fakat çocuklarının davranışlarını kontrol etmek ve çocuğun davranışlarına sınırlar koymak için uygun ve sürdürülebilir kurallar koymazlar (Power, 2013). Bu ebeveynler çocuklarının ilgi ve ihtiyaçlarına nispeten duyarlıdır, ancak çocuklarından beklentileri ve çocuklarının uyması gereken kurallar konusunda umursamaz davranır ve bunlar için çaba göstermezler (Darling ve Steinberg, 1993; Spera, 2005). Son olarak, ihmalkâr ebeveynler ise çocuklarına ne sıcaklık ne de kontrol davranışı gösterirler; çocukları ile ilgilenmez, alakadar olmazlar (Darling ve Steinberg, 1993). Bu ebeveynlik stili, alan yazında nispeten nadiren çalışılmakla beraber, çocuklarda olumsuz davranışsal çıktılar ile ilişkilendirilmiştir (Darling ve Steinberg, 1993; Pinquart, 2017a; 2017b).

Ebeveynlik stilleri ve çocuklardaki beden kitle indeksi ilişkisi üzerine gerçekleştirilen araştırmalar ailenin çocuğa yönelik gösterdiği ebeveynlik stillerinin çocuğun beslenme alışkanlıkları ve ağırlık durumu üzerinde etkili olduğuna (Scaglioni ve ark., 2011; Ventura ve Birch, 2008) ve obezite/yüksek tartılılık problemlerinin ortaya çıkmasında önemli rol oynadığına işaret etmektedir (Enten ve Golan, 2008). Ebeveynler çocuklarına besinler ve yeme konusunda tecrübe edinecekleri ilk ortamı sağla- 
makta, dolayısıyla çocuklarının ilk yeme davranışlarının oluşmasında rol model olarak işlev görmektedirler (Birch ve Davison, 2001). Bu nedenle ebeveynlik stilleri ve davranışları çocukların beden kitle indeksi ile yakından ilişkilidir.

Yapılan araştırmalar yetkili/demokratik ebeveynlik stilinin, diğer ebeveynlik stilleri ile karşılaştırıldığında, çocukların daha fazla sağlıklı besin tüketimi ve daha düşük obezite riski ile ilişkili olduğunu göstermiştir (Chen ve Kennedy, 2004; Kremers ve ark., 2003; Sleddens ve ark., 2011). Örneğin, ergenlik çağında ebeveynlerini "yetkili/demokratik ebeveyn" olarak tanımlayan bireylerin diğer ebeveynlik stilleri ile yetiştirilmiş bireylere göre daha fazla meyve tükettiği ve meyve tüketimine dair tutumlarının daha olumlu olduğu tespit edilmiştir (Kremers ve ark., 2003). Benzer bulgular Çin'de ve ABD'de yaşayan Çinli-Amerikalı çocuk ve ergenlerde de gösterilmiştir (Chen ve Kennedy, 2004; Kim ve ark., 2008). Genel olarak annelerin yüksek sıcaklık göstermesi daha az kalori alımı ve düşük yağ tüketimi, dolayısı ile düşük beden kitle indeksi ile ilişkilendirilmiştir (Kim ve ark., 2008). Boylamsal olarak gerçekleştirilen çalışmalar da kesitsel çalışmaları destekler nitelikte yetkili/demokratik ebeveynler tarafından yetiştirilmiş çocukların daha sağlıklı olduğunu ve dolayısıyla daha az obezite problemi yaşadığını belirlemiştir (ör. Berge ve ark., 2010; Lohaus ve ark., 2009). Yetkili/demokratik ebeveynlerin yeme esnasında da çocuklarına doğru oranda kontrol gösterdikleri, yeme durumlarında aşırı müdahaleci olmadıkları ve bu nedenlerle çocukluk çağındaki obezite problemlerinin yetkili/demokratik ebeveynlere sahip çocuklarda daha az olabileceği öne sürülmüştür (Enten ve Golan, 2008; Hughes ve ark., 2005). Ayrıca yetkili/demokratik ebeveynlik davranışının içinde tanımlanan sıcaklık gösterme ve duyarlılık (Wong ve ark., 2021) davranışları, bağlanma kuramına göre güvenli bağlanmanın temellerini oluşturmaktadır (Cassidy, 2008; Weinfield ve ark., 2008). Güvenli bağlanma ise daha düşük obezite riski ile ilişkilendirilmektedir (ör. Anderson ve Whitaker, 2011). Dolayısıyla, çocuklardaki farklı olumlu çıktılarla eşleştirilen yetkili/demokratik ebeveynlik davranışının başka bir olumlu çıktısının çocuklardaki daha düşük obezite riski olduğu görülmektedir.

Otoriter ebeveynlik ise pek çok çalışma tarafından çocukluk ve ergenlik çağında obezite için önemli bir risk faktörü olarak belirlenmiştir (Berge ve ark., 2010; Fuemmeler ve ark., 2012; Pace ve ark., 2019; Yavuz ve Selçuk, 2018). Ebeveynler tarafindan yüksek derecede uygulanan kontrol davranışlarının yemek yeme de dahil olmak üzere çeşitli alanlarda çocukların kendilerini denetleme becerilerini sınırlandırdığı gözlemlenmiştir (Francis ve Susman, 2009; Grolnick ve Farkas, 2002). Öz denetim becerisi yeme davranışları ile ilişkili olduğundan araştır- malar otoriter ebeveynliğin obezite gelişimi için önemli bir risk faktörü olduğunu belirtmiştir (Golan ve Bachner-Melman, 2011; Rollins ve ark., 2016). Kesitsel araştırmalar, otoriter ebeveynlere sahip çocukların yetkili/ demokratik ebeveynlerin çocuklarına kıyasla hem okul öncesi dönemde hem de okul çağında obez olma riskinin daha fazla olduğunu tespit etmiştir (Kakinami ve ark., 2015; Pace ve ark., 2019). Ayrıca, ülkemizde okul öncesi dönemdeki çocuklar ve anneleri ile yapılan bir çalışma anneleri otoriter olan çocukların obezite için yaklaşık 1,5 kat daha fazla risk altında olduğunu bulgulamıştır (Yavuz ve Selçuk, 2018). Boylamsal çalışmalar da genel olarak bu bulguları destekler niteliktedir (Connell ve Francis, 2014; Lane ve ark., 2013; Lohaus ve ark., 2009). Örneğin, ilköğretim çağındaki çocuklar ve ebeveynlerini 3 yıl süreyle inceleyen bir çalışma, otoriter ebeveynlere sahip çocukların araştırma süreci boyunca sağlığa ilişkin olumlu davranışları (iyi beslenme, fiziksel aktivite vb.) yetkili/demokratik ebeveynlerin çocuklarına göre daha az gösterdiğini tespit etmiştir (Lohaus ve ark., 2009). Dolayısıyla, bulgular yüksek derecede kontrol içeren ve çocuğun kararlarına saygının az olduğu otoriter ebeveynlik stilinin, yeme davranışları üzerine de çocukların karar verme mekanizmalarını etkileyerek öz denetim becerilerini olumsuz etkilemekte olduğunu ve obezite riskini artırdığını önermektedir.

İzin verici/hoşgörülü ebeveynlik ile ilgili çalışmalar sayıca daha azdır ve çelişkili sonuçlar göstermektedir. Kimi çalışmalar izin verici ebeveynlik ile çocuklardaki beden kitle indeksi arasında bir ilişki bulamazken (ör. Agras ve ark., 2004; Blissett ve Haycraft, 2008), diğer çalışmalar izin verici/hoşgörülü ebeveynlik stili gösteren ailelerin çocuklarının daha yüksek beden kitle indeksine sahip olduğunu (ör. Humenikova ve Gates, 2008; Olvera-Ezzell ve Power, 2009; Rhee ve ark., 2006; Volmer ve Mobley, 2013) ve beslenme ve fiziksel aktivite bağlamında obezite riskini artırıcı davranışların bu ailelerde daha yaygın olabildiğini (ör. Johnson ve ark., 2012) göstermiştir. Okul öncesi ve okul çağındaki çocuklarla gerçekleştirilen boylamsal bir çalışma da izin verici/hoşgörülü ebeveynlik stili gösteren annelerin çocuklarının, 3 yıllık süreç sonunda diğer çocuklara göre aşırı kilolu olma ihtimallerinin daha fazla olduğunu tespit etmiştir (Olvera ve Power, 2009). Bununla beraber, tersi bulgular da mevcuttur. Örneğin, izin verici/hoşgörülü ebeveynlerin çocuklarının otoriter ebeveynlerin çocuklarına oranla daha fazla sebze-meyve tükettiği ve meyve tüketimine dair bilișlerinin daha olumlu olduğuna yönelik kesitsel ve boylamsal bulgular bulunmaktadır (ör. Berge ve ark., 2010; Kremers ve ark., 2003). Okul öncesi dönemdeki çocukları ilkokul birinci sınıfa kadar takip eden boylamsal bir araştırmada otoriter ebeveynlerin çocuklarının yetkili/demokratik ebeveynlerin çocuklarına göre daha 
yüksek beden kitle indeksine sahip olduğu ve daha sağlıksız beslendiği; bununla beraber izin verici/hoşgörülü ebeveynlik stiliyle yetiştirilen çocukların da yetkili/ demokratik ebeveynlerin çocuklarına göre iki kat daha fazla obezite riski taşıdığ 1 belirlenmiştir (Rhee ve ark., 2006). Dolayısıyla izin verici/hoşgörülü ebeveynliğin çocukların beslenmesi için otoriter ebeveynliğe oranla daha olumlu olabileceği gösterilmiştir. Bulgular bütünüyle ele alındığında izin verici/hoşgörülü ebeveynlik davranışının obezite gelişimi için risk içerebileceği görülmektedir. Fakat bu ebeveynlik stili ile ilgili bulgular net değildir ve kavramsal olarak da net açıklanmamıştır.

Kimi çalışmaların ebeveynlik stilleri ile ilgili farklı sonuçlar göstermesine rağmen (ör. Agras ve ark., 2004; Blissett \& Haycraft, 2008; De Bourdeaudhuij ve ark., 2009; ayrıca bk. Enten ve Golan, 2008), özellikle otoriter ebeveynlik risk faktörü olarak belirlenirken, yetkili/ demokratik ebeveynlik stili obezite için koruyucu bir faktör olarak ortaya çıkmaktadır. Ayrıca, ebeveynlik stillerini hedef alan obezite müdahale programlarından da olumlu sonuçlar alınmıștır. Bu konuda yapılan pek çok araştırma, olumlu ebeveynlik davranışlarını arttırmayı hedefleyen müdahale programlarının çocukların beden kitle indeksleri ile ilgili sonuçları olumlu etkilediği neticesine varmıştır (Bocca ve ark., 2012; Brotman ve ark., 2012; Quattrin ve ark., 2012; Stark ve ark., 2011). Örneğin Brotman ve arkadaşları (2012) tarafından gerçekleştirilen müdahale çalışmasında okul öncesi çağda çocukları olan ebeveynlere olumlu ebeveynliğin artırılmasına yönelik eğitim verildiğinde (ör. çocuğa gösterilen sıcaklık ve duyarlığın artırılması ve çocuk üzerinde uygulanan olumsuz kontrol davranışlarının azaltılması), 5 yıllık süreçte çocukların beden kitle indeksinde daha az artış gözlenmiştir. Devam eden 5 yıl boyunca da çocukların daha düşük beden kitle indeksine sahip olduğu ve daha az obezite riski taşıdıkları tespit edilmiştir (Brotman ve ark., 2012). Ek olarak, yapılan müdahale çalışmaları ebeveynlerin davranış ve ebeveynlik stillerine yapılan müdahalenin obeziteyi önlemede sadece çocuklar ile yapılan müdahalelere oranla daha etkili olduğunu belirlemiştir (ör. Bocca ve ark., 2012; Brotman ve ark., 2012; Golan ve Crow, 2004; Quattrin ve ark., 2012; Stark ve ark., 2011). Bu bulgular ebeveynlik stillerinin çocukluk çağındaki obezitenin gelişimi üzerindeki önemini göstermektedir. Erken yaşta obezite ile mücadele etmek için bu konuda daha fazla araştırmaya ve çocukların sağlı̆̆ için ebeveynlerin bilgilendirilmesine ihtiyaç vardır.

\section{Çocuk Mizacı ve Obezite}

Ebeveynlerin çocuklarını besleme davranışları, ebeveynlik davranışları ve stilleri gibi çevresel faktörler obezite ve yüksek tartılılık problemlerinin ortaya çıkmasında belirleyici rol oynasa da, bazı çocuklar yüksek tartılı veya obez olmaya veya çevresel faktörlerden etkilenmeye diğer çocuklara kıyasla daha fazla yatkınlık göstermektedir. Yapılan araştırmalar çocukların doğuştan gelen mizaç özelliklerinin yeme davranışlarına etki ettiğini, dolayısıyla obezite riskinin ortaya çıkmasında önemli rol oynayabileceğini göstermiştir (derleme için bk. Anzman-Frasca ve ark., 2012). Mizaç, bireylerin zaman içinde olgunlaşma ve deneyimlerden etkilenebilen ancak görece sabit kalıtımsal farklılıkları olarak tanımlanmaktadır (Rothbart ve ark., 2000). Çocukların mizaç özellikleri çevresel faktörler karşısında çok fazla değişiklik göstermemektedir ve genetik faktörlerden etkilenmektedir (Sanson ve ark., 2011). Bu nedenle mizaç obezitenin değişime çok fazla açık olmayan yordayıcılarından biri olarak kabul edilmektedir (Agras ve Mascola, 2005). Çocukluk çağındaki mizaç özellikleri farklı şekilde tanımlansa da araştırmalar tarafından en sıklıkla çalış1lan mizaç özellikleri olumlu duygulanım (positive affectivity), olumsuz duygulanım (negative affectivity) ve kendini ketleme becerisidir (inhibitory control) (Yavuz, Korucu ve Selçuk, 2022). Bu nedenle mevcut derlemede mizaç özellikleri bu üç alt başlıkta ele alınmıștır. Olumlu duygulanım olumlu ruh hali, gülümseme, kahkaha atma gibi duygulanımları; olumsuz duygulanım kızgınlık, mutsuzluk, korkulu olma, çekingenlik gibi duygulanımları içermektedir; kendini ketleme becerisi ise çocuğun duygularını ve davranışlarını denetleme becerisini ifade etmektedir (Rothbart ve ark., 2000). Mizaç özelliklerinin hem doğrudan hem de ebeveynlik davranışlarını etkileyerek dolaylı yollardan çocuklardaki gelişimsel çıktılar ve obezite ile ilişskili olduğu gösterilmiştir. Özellikle olumsuz duygulanım ve düşük ketleme becerisi kuramsal ve deneysel olarak çocuklarda yeme davranışı ve obezite ile ilişkilendirilmiştir (bk. Anzman-Frasca ve ark., 2012; Bergmeier ve ark., 2013; Bergmeier ve ark., 2014).

Yapılan araştırmalar, çoğunlukla yüksek düzeyde olumsuz duygulanımı yüksek beden kitle indeksi ve obezite riski ile ilişkilendirmiştir. Pek çok araştırma olumsuz duygulanımı yüksek olan çocukların anneleri tarafından daha fazla sağlıksız gıdalar ile beslendiğini bulgulamıştır (derleme için bk. Bergmeier ve ark., 2014). Olumsuz duygulanımı yüksek olan çocuklar bebeklik ve okul öncesi dönemlerde genellikle daha huysuz olabilmekte, yatıştırılmaları daha zor olabilmekte ve yemek için daha fazla öfke nöbeti geçirebilmektedirler. Bu da annelerin çocuklarını yatıştırmak için yemeği kullanmasina sebep olabilmektedir (Agras ve ark., 2004; Stifter ve ark., 2011). Bebeklik ve çocukluk çağlarındaki olumsuz duygulanım ile ilişkili olarak annenin yatıştırmak için besleme yöntemine daha sık başvurmasının ise kişilerin ileride duygusal durumlar karşısında yemek yeme davranışını artırabileceği önerilmiştir (Anzman-Frasca ve 
ark., 2012; Braden ve ark. 2014; Stifter ve ark., 2011). Küçük yaşlarda duygularını yatıştırmak amacıyla yedirilen çocukların yemek yemeyi açlık ile değil, duygusal durumlarla ilişkilendirme olasılığı artabilmektedir. Dolayısıyla bebeklik çağında olumsuz duygulanıma sahip olan çocuklar anneleri tarafindan duygusal durumlarına karşılık olarak daha fazla beslenme riski altında olmakta, çocuklar beslenmek ile duygusal durumları birbiriyle eşleştirebilmekte ve duygusal durumlarda daha fazla yeme davranışı gösterebilmektedir. Bunun sonucunda sonraki dönemlerde de bireylerin açlık/tokluk hissi yerine duygusal durumlar üzerine yeme davranıșı gösterme ve dolayısıyla obezite/yüksek tartılı olma riski artabilmektedir.

Bazı kesitsel araştırmalar bu yargıları desteklemese de (ör. Yavuz ve Selçuk., 2018), pek çok araştırma bu yargıyı destekler niteliktedir. Örneğin, Norveç'te 18 aylik bebekler ve annelerinden oluşan toplamda 40 bini aşkın katılımcıyla gerçekleştirilen bir araştırma, yüksek derecede olumsuz duygulanıma sahip, kaygılı ve korkulu çocukların anneleri tarafından daha fazla şekerli yiyecek ve içecek ile beslendiğini göstermiştir (Vollrath, Tonstad, Rothbart ve Hampson, 2011). Başka bir araştırmada anneleri tarafindan olumsuz duygulanımı ve besin seçiciliği yüksek olarak algılanan 3 aylık bebeklerin, sıklıkla anne sütünün yanında ek gıda ile beslendiği bulgulanmıştır (Wasser ve ark., 2011). Pearce, Taylor ve Langey-Evans (2013) çalışmasına göre erken dönemde başlanılan ve sıklıkla verilen ek gıda ise çocuklarda obezite riskini artırabilmektedir. Çocukların mizacı ve beden kitle indeksi arasındaki ilişkiyi inceleyen boylamsal araştırmalarda da benzer sonuçlar elde edilmiştir (ör. Vollrath ve ark., 2011; Vollrath ve ark., 2012). Yukarida bahsedilen, Vollrath ve arkadaşlarının (2011) Norveç’te 40 binden fazla çocukla gerçekleştirdiği araştırmanın devamı niteliğinde olan bir çalışmada 1,5 yaşındayken üzgün, korkulu ve kaygılı olan çocukların 3 ve 7 yaşlarına geldiklerinde daha fazla şekerli yiyecek ve içecek tükettikleri belirlenmiştir (Vollrath ve ark., 2012). Özetle, alan yazında olumsuz duygulanımın hem kisa hem de uzun vadede besin tüketimi ve obezite riski ile ilişkisi olduğu önerilmektedir.

Olumsuz duygulanımın yanı sıra, obezite için risk faktörü olarak değerlendirilen bir diğer mizaç özelliği de kendini ketleme becerisidir. Mizaç ve obezite ile ilgili yapılan derleme çalışmaları kendini ketleme (inhibitory control) veya öz-denetim (self-regulation) mizaç özelliklerinin düşük olmasının obezite için risk faktörü olabileceğini ortaya koymuştur (Anzman-Frasca ve ark., 2012; Bergmeier ve ark., 2014). Kendini ketlemede sorun yaşayan çocukların yeme davranışını denetlemekte de sorun yaşayacakları, özellikle obezite riskini arttırıcı ortamlara (ör. yüksek kalorili yiyeceklerin sürekli erişimleri dahilinde olması gibi) maruz kalmaları halinde daha yüksek kalorili yemekleri yeme konusunda kendilerini ketleme davranışı gösteremeyecekleri, dolayısıyla daha fazla besin tüketip daha yüksek obezite riskinde olacakları belirtilmiştir (Francis ve Susman, 2009; Johnson ve Birch, 1994). Bu yargıyı destekler şekilde, 4-6 yaş arasındaki çocuklar ve ebeveynleriyle gerçekleştirilen bir araştırmada laboratuvar ortamında çocukların yeme davranışları gözlemlenmiş, sonuç olarak kendini ketleme becerisi yüksek olan çocukların iki atı̧şırmalık (çikolata ve üzüm) arasından sağlıklı olanı tercih etmeye daha yatkın oldukları tespit edilmiştir (Zhou ve ark., 2019). Boylamsal bir araștırmada ise, 3 yaşındayken öz-denetim becerisi yüksek olan çocukların 5 yaşına geldiklerinde diğer çocuklara göre daha sağlıklı beslendikleri ve daha sağlıklı yeme ve fiziksel aktivite alışkanlıklarına sahip oldukları gözlemlenmiştir (van den Heuvel ve ark., 2017). Dolayısıyla yüksek kendini ketleme becerisi hem kesitsel hem de boylamsal bulgular ile obezite için önemli bir koruyucu faktör olarak belirlenmiştir.

Obeziteyle ilişki içerisinde araştırılan bir diğer mizaç özelliği olumlu duygulanımdır ve bu konuya dair yapılmış araştırmaların bulguları çeşitlilik göstermektedir. Örneğin, okul öncesi çocuklarla yapılan bir araştırmada yüksek olumlu duygulanımın çocuklarda dışsal uyaranlara bağlı olarak aşırı yeme, sıklıkla yeme isteği, yemekten keyif alma ve aç olunmadığı halde yemek yeme davranışları ile olumlu yönde ilişki gösterdiği bulunmuştur (Leung ve ark., 2014). Fakat bu bulguyla uyumsuz şekilde, pek çok çalışma olumlu duygulanım ile çocukların beden kitle indeksi arasında önemli bir ilişki tespit edememiştir (derleme için bk. Bergmeier ve ark., 2014). Ek olarak, bazı çalışmalar olumlu duygulanımın diğer mizaç özellikleri ile birleştiğinde (ör. düşük öz-düzenleme becerisi) çocukların yeme davranışlarına olumsuz yönde etki edebileceğini göstermiştir (ör. Zhou ve ark., 2019). Bu bulgular ise mizaç özelliklerinin tek başına değil başka kişisel ve çevresel faktörler ile etkileşim halinde incelenmesinin ve bu etkilerin de analizlerde kontrol edilmesinin önemine işaret etmektedir.

Yukarıdaki tartışmayı destekler şekilde, mizaç ve obezite ilişkisini inceleyen çalışmaların bazıları mizaç ile obezitenin, özellikle farklı demografik karakteristikler (ör. anne beden kitle indeksi) kontrol edildiğinde istatistiksel olarak anlamlı olmayabileceğini önermiştir (ör. Haycraft ve ark., 2011; Yavuz ve Selçuk, 2018). Mizaç özelliklerinin belli ebeveynlik davranışlarını (ör. yatıştırmak için yedirme) yordayabileceği öngörülse de, mizaç her zaman ebeveynlik davranıșlarının öncülü değildir. Keza, mizaç ve obezite ilişkisini inceleyen iki derleme çalışması bu konudaki çalışmaların net sonuçlar göstermediğini belirlemiştir (Anzman-Frasca ve ark., 2012; Bergmeier ve ark., 2014). Mizaç özelliklerinin genetik kökenli olduğu göz önünde bulundurulduğunda, mizacın 
çocukların beden ağırlığı ve yeme davranışlarına olan etkisinin anne ve babaların gösterdiği ebeveynlik davranışlarıyla etkileşim içinde incelenmesi daha net ve tutarlı bulgular elde edilmesini sağlayacaktır. Çocuk mizacını ebeveynlere ilişkin farklı değişkenlerle birlikte ele alan çalışmalar bu yargıyı destekler niteliktedir. Örneğin, çocukların ağırlık durumunu 6 aydan ilköğretim 6. sınıfa dek takip eden bir araştırmada, zor mizaca (bk. yüksek olumsuz duygulanım, düşük kendini ketleme becerisi) sahip olup, ek olarak anneleri duyarsız ebeveynlik davranışlar gösteren çocukların daha fazla yüksek tartılılık ve obezite riski altında olduğu tespit edilmiştir ( $\mathrm{Wu}$ ve ark., 2011). Bu çalışma mizaç özelliklerinin farklı diğer değişkenlerle ilişkili olarak etkilerinin araştırılmasının önemine işaret etmekte ve bu alanda yapılabilecek araștırmalar için yol gösterici olmaktadır. Özetle, mizaç özelliklerinin obeziteye olan etkisinin incelenmesi, özellikle mizaç ve ebeveynlik bağlamlarının birlikte incelenip bu faktörler arasında etkileşimli etkilerin ve/veya aracı değişken etkilerinin olup olmadığının belirlenmesi çok önemlidir. Ayrıca ebeveynlik davranışlarına ve stillerine benzer şekilde bu ilişkilerin sadece kesitsel değil, boylamsal şekilde de incelenmesi alan yazındaki bilgi birikimine çok büyük katkılar sağlayacaktır.

\section{Tartışma}

Obezite çağımızda hızla artmakta olan ve hem çocukluk çağında hem de yetişkinlikte pek çok olumsuz sonuç ile ilişkilendirilen bir sağlık problemidir. Obezite ile mücadelenin hem bireyler için hem de devletler için ekonomik maliyeti de çok fazladır (Finkelstein ve ark., 2005; Withrow ve Alter, 2010). Bu nedenle obeziteye yönelik önleyici müdahale çalışmalarının gerçekleştirilmesi çok önemlidir. Obeziteye yol açan alışkanlıklar genellikle çocukluk çağında edinilmektedir ve obezite çocukluk çağındaki yaşantılardan etkilenen bir problemdir (Birch ve Davison, 2001; Gahagan, 2012; Olvera-Ezzell ve ark., 1990; Patrick ve Nicklas, 2005; Scaglioni ve ark., 2008). Bu nedenle obezitenin özellikle çocukluk çağındaki en önemli öncüllerinin belirlenmesi, bu alanda yapılacak müdahale programları için çok önemli bir zemin oluşturmaktadır. Önceki araştırmalar ebeveynlerin çocuk besleme davranışlarının, ebeveynlik stillerinin ve çocukların mizaç özelliklerinin obezitenin çocukluk çağındaki önemli belirleyicilerinden olduğunu göstermiştir ve mevcut çalışmada bu alandaki ulusal ve uluslararas1 yayınların bir derlemesi verilmiştir. Pek çok araştırma kısıtlayıcı beslemeyi, otoriter ebeveynliği, olumsuz duygulanım ve düşük ketleme becerisi gibi mizaç özelliklerini yüksek beden kitle indeksi ve obezite riski ile ilişkilendirirken; yeme için baskı ve yetkili/demokratik ebeveynlik ise düşük obezite riski ve/veya daha sağlıklı beslenme ile ilişkilendirilmiştir. Genellikle boylamsal çalışmalar da bu bulguları destekler niteliktedir, fakat çelişkili sonuçlar gösteren ve bu bulguları doğrulamayan çalışmaların da sayısı azımsanamayacak kadar fazladır.

Bulgular arasındaki uyuşmazlık, kısmen araştırmaların metodolojik farklılıkları ile açıklanabilir. İlk olarak çoğu araştırmada kullanılan değişkenler farklılık göstermektedir. Bazı araştırmalar araştırma çıktısı olarak beden kitle indeksini ele alırken (ör. Wake ve ark., 2007), bazıları çocukların obez/yüksek tartılı olup olmadığını ölçmüş (ör. Jansen ve ark., 2016), bazıları ise yalnızca sağlıksız besinlerin veya meyve/sebze gibi sağlıklı besinlerin tüketim miktarlarını incelemiştir (ör. Brown ve ark., 2008). Dolayısıyla, benzer iddialarda bulunmakla birlikte ölçülen sonuç değişkenlerinin farklı olması çalışmalardaki farklılıkların olası bir sebebi olabilir. Ayrıca kimi araştırmalar demografik değişkenleri istatistiki olarak kontrol ederken (ör. Rhee ve ark., 2006), kimileri etmemiş (ör. Rodgers ve ark., 2013) ve ekseriyetle farkl1 araştırmalar farklı demografik değişkenleri kontrol etmiștir (ör. Wake ve ark., 2007). Demografik değișkenler (ör. anne baba kilosu, sosyoekonomik düzey, çocuk yaşı) de obezite riskinde belirleyici faktörler olabildiğinden (Cooke ve ark., 2004; Gibson ve ark., 2007; Patrick ve Nicklas, 2005; Loth ve ark., 2013; Reilly ve ark., 2005) bu değișkenlerin kontrol edilip edilmemesi sonuçlardaki farklılıkların bir başka sebebi olabilir.

Çocukların içinde bulundukları yaş grubu, yeme alışkanlıklarında ve ebeveynler tarafından gösterilen besleme davranışlarında belirleyici bir faktör olabilir. Örneğin, çocukların yemeye karşı direnci ve ebeveynlerin çocuklara yemek için baskı uygulama davranışı 3 yaşından 4 yaşına dek azalabilmektedir (Powell ve ark., 2018). Kısıtlayıcı besleme davranışlarının 5-6 yaş ve 10-12 yaş grubundaki çocuklarda farklı etkileri olduğu önerilmiş; erken yaşta uygulanan kısıtlama davranıŞ1 çocukların obezite riskini artırabilirken, daha ileriki yaşlarda aynı davranışın çocukların sağlıklı kilolarını korumalarını sağlayabildiği belirlenmiştir (Campbell ve ark., 2010). Dolayısıyla çocukların yaşları, ebeveynlerin kullandıkları besleme stilleri ve çocukların beden kitle indeksi arasındaki ilişkiyi etkileyebilmektedir. Ek olarak, çocukların yeme davranışları yaşlarına bağlı olarak değişebilmekte, ebeveynlerin besleme stilleri de zaman içinde bu değişime göre şekillenebilmektedir. Tüm bu farklılıklar, alan yazındaki birbiri ile tutarlı olmayan bulguları kısmi olarak açıklayabilir.

Alan yazındaki belirsizliğin olası sebeplerinden bir tanesi de boylamsal ve deneysel çalışmaların sayısının çok az olmasıdır. Aksinin belirtildiği durumlar haricinde, özetlenen araştırmaların pek çoğu kesitsel desen kullanmış, dolayısıyla çocukların beden kitle indeksini ve annelerin besleme davranışlarını eş zamanlı olarak ölçmüştür. 
$\mathrm{Bu}$ ölçüm yöntemi ilişkinin düzeyi ve yönü ile ilgili bilgi vermekle birlikte ilişki kapsamında hangi değişkenin öncül olduğu ile ilgili bilgi vermemektedir. Dolayısıyla anne davranışları ile obezite arasındaki ilişkide anne davranışları öncül olabileceği gibi (anne davranışlarının çocuğun obezitesinin sebebi olduğu durum), çocukların beden kitle indekslerinin öncül olması da (obezite problemi olan çocukların annelerinden farklı davranışlar görmeleri durumu) olasıdır. Buna göre, örneğin, anneleri besleme davranışı olarak yüksek kısıtlayıcı besleme uygulayan çocukların daha yüksek beden kitle indeksine sahip olması kadar olası olan bir başka seçenek, yüksek tartılı ve obez olan çocukların yeme davranışlarının anneleri tarafından daha fazla kısıtlanıyor oluşu; yani etkinin çocuktan anne davranışına doğru olmasıdır. Dolayısıyla kesitsel çalıșmalar sonucunda hangi davranışın öncül olduğu net değildir. Boylamsal çalışmaların ise sayısı azdır ve gerçekleştirilen boylamsal araştırmalar her iki yöndeki etki için de destek göstermiştir. Kimi çalışmalar boylamsal olarak önceki zamandaki çocuk beden kitle indeksinin sonraki zamandaki anne besleme davranışlarına etkisini gösterirken (bk. Webber ve ark., 2010; Pesch ve ark., 2016), başka boylamsal araştırmalar annelerin besleme davranışlarının öncül olduğunu, çocukların beden kitle indeksinin ise annelerin davranışlarına bağlı olarak değiştiğini önermiştir (bk. Birch ve ark., 2003; Rodgers ve ark., 2013). Ek olarak, neden-sonuç ilişkisinin belirlenmesini sağlayabilecek deneysel çalışmalar da yok denecek kadar azdır. Çocukların beden kitle indeksi ve ebeveynlerin besleme stilleri ile davranışları arasındaki ilişkinin yönünün net olarak belirlenebilmesi, neden sonuç ilişkilerinin daha net ortaya konabilmesi ve erken yaşta obeziteye müdahale programlarının geliştirilebilmesi için daha fazla boylamsal ve deneysel araştırmaya ihtiyaç vardır. Alan yazındaki çelişkili sonuçlar ele alındığında, benzer metodolojik yöntemler kullanan ve anne davranışları ile çocuklardaki gelişimsel çıktıları farklı zaman dilimlerinde ölçen boylamsal araştırmaların da artması ile birlikte bu konudaki belirsizliğin ortadan kalkması için önemli adımlar atılacaktır.

Alan yazındaki önemli bir diğer eksiklik ise neredeyse tüm çalışmaların anneler ile yapılmış olması ve babalar ile yapılan çalışmaların görece az olmasıdır. Babalar çocuk yetiştirmede önemli rol oynasalar da anneler halen birincil bakım veren konumundadır ve babaların rolü en iyi ihtimalle ikincil/yardımcı bakım veren statüsünde görülmektedir (Campbell ve ark., 2010; Wall ve Arnold, 2007). Özellikle çocukların beslenmesi ve yedirilmesinde anneler babalara göre daha fazla sorumluluk üstlenmekte (Blissett ve ark., 2006) ve babalara kıyasla çocuklarıyla daha sık şekilde öğünlerde beraber olmaktadırlar (Haycraft ve Blissett, 2008;2012). Günümüzde bu dengeler değişmekle birlikte, araştırmalarda babalar hala eşit derecede temsil edilmemektedir (bk. Khandpur ve ark., 2014). Bununla beraber, babaların çocuk besleme davranışlarını inceleyen araştırmalar babaların da çocukların ağırlık durumu ve obezite riskinde etkili olduğunu önermektedir (Fraser ve ark., 2011; Khandpur ve ark., 2014). Babalar yemek için baskı uygulama, yenilen besin miktarını kontrol etme ve kısitlama davranışlarını annelere kıyasla daha fazla gösterebilmektedir (Hendy ve ark., 2009; Pulley ve ark., 2014; Tschann ve ark., 2013). Öğünlerin planlanması, besin miktarı ve doğru yiyecekleri seçme gibi konularda babalar da etkin rol oynayabilmekte ve çocukların beslenmesi ile ilgili sorumluluğu paylaşabilmektedir (Mallan ve ark., 2013; 2014). Bu nedenle, ailelerin bütüncül bir şekilde temsil edilebilmeleri için alan yazında babalarla yapılan çalışmaların arttırılması önem arz etmektedir.

Sonuç olarak obezite dünyada ve ülkemizde artmakta olan bir sorundur ve temelleri çocukluk çağında atılmaktadır. Obezite ile mücadele kapsamında pek çok müdahale çalışması kurgulanmış ve başarı ile uygulanmıștır (bk. Yavuz ve ark., 2015). Farklı meta analiz çalışmalarında, özellikle ebeveynlerin dahil edildiği müdahale çalışmalarının ebeveynleri kapsamayan çalışmalara göre daha etkin olduğuna işaret edilmiştir (ör. Niemeier ve ark., 2012; Young ve ark., 2007). Çocukların yeme alışkanlıkları ve fiziksel aktivite düzeyleri gibi değişkenlere odaklanan müdahale çalışmalarına kıyasla, genel ebeveynlik becerileri ve davranışlarına da yer veren müdahale çalışmalarının (ör. Bocca ve ark., 2012; Brotman ve ark., 2012) obeziteye karş1 daha koruyucu bir etkisi olduğu önerilmektedir (Yavuz ve ark., 2015). Bunun yanında müdahale çalışmalarının erken çocukluk yıllarında (ör. okul öncesi dönem) başlatılması da müdahalelerin uzun vadede etkin olmasında önemli bir faktör olarak görülmektedir (Fitzgibbon ve ark., 2005; Nemet ve ark., 2013; Stark ve ark., 2011; Yavuz ve ark., 2015). Fakat müdahale çalışmaları nadiren obezitenin öncüllerinin tamamını (mizaç özellikleri, ebeveynlik bilişleri, davranışları, stilleri, demografik faktörler) bir arada ele almayı hedeflemiştir (Foster ve ark.., 2020). Mevcut derlemede de görüldüğü gibi obezite farklı içsel ve dişsal risk ve koruyucu faktörlerden etkilenmektedir. Dolay1sıyla, erken yaşta müdahale programlarının kapsayıc1lıkları arttırılarak geliştirilip uygulanması büyük önem taşımaktadır. Erken çocukluk döneminde uygulanacak müdahale programları, obezite sorununun etkili ve daha düşük maliyetle çözülmesi için önemli bir adım olacaktır (Yavuz ve ark., 2015), ancak daha net hedefler belirleyebilmek adına daha fazla araştırmaya ihtiyaç duyulmaktadır. Bu derlemenin sonuçları ebeveynlik stilleri, bilişleri ve çocuklarını besleme davranışları ile çocukların mizaç özelliklerinin çocukların sağlıklı vücut ağırlığını korumasındaki bütüncül önemini vurgulamaktadır. 


\section{Kaynaklar}

Agadayı, E., Çelik, N., Çetinkaya, S. ve Karaca, S. N. (2019). Sivas ili kırsal bir ilçede okul çağı çocuklar ve adolesanlarda obezite sıklığının ve etkileyen faktörlerin belirlenmesi. Ankara Medical Journal, 19(2), 325-336. https://doi.org/10.17098/amj.571393

Agras, W. S., Hammer, L. D., McNicholas, F., ve Kraemer, H. C. (2004). Risk factors for childhood overweight: a prospective study from birth to 9.5 years. The Journal of Pediatrics, 145(1), 20-25. https://doi.org/10.1016/j.jpeds.2004.03.023

Agras, W. S., \& Mascola, A. J. (2005). Risk factors for childhood overweight. Current opinion in pediatrics, 17(5), 648-652. https://doi. org/10.1097/01.mop.0000172818.87261.ab

Aksakal, B. Y. ve Oğuzöncül, A. F. (2017). Elazığ Kent Merkezinde Bulunan Ortaöğretimde Okuyan Öğrencilerde Obezite Sıklığı ve Etkileyen Faktörlerin İncelenmesi. Dicle Tip Dergisi, 44(1), 13-24. https://doi.org/10.5798/dicletip. 298575

Alper, Z., Ercan, İ. ve Uncu, Y. (2018). A Meta-Analysis and an Evaluation of Trends in Obesity Prevalence among Children and Adolescents in Turkey: 1990 through 2015. Journal of Clinical Research in Pediatric Endocrinology, 10(1), 59-67. https://doi. org/10.4274/jcrpe.5043

Anderson, S. E., ve Whitaker, R. C. (2011). Attachment security and obesity in US preschool-aged children. Archives of Pediatrics \& Adolescent Medicine, 165(3), 235-242. https://doi.org/10.1001/ archpediatrics.2010.292

Anzman-Frasca, S., Stifter, C. A. ve Birch, L. L. (2012). Temperament and childhood obesity risk: a review of the literature. Journal of Developmental \& Behavioral Pediatrics, 33(9), 732-745. https://doi. org/10.1097/DBP.0b013e31826a119f

Batsell Jr, W. R., Brown, A. S., Ansfield, M. E. ve Paschall, G. Y. (2002). "You will eat all of that!": A retrospective analysis of forced consumption episodes. Appetite, 38(3), 211-219. https://doi. org/10.1006/appe.2001.0482

Baughcum, A. E., Chamberlin, L. A., Deeks, C. M., Powers, S. W., ve Whitaker, R. C. (2000). Maternal perceptions of overweight preschool children. Pediatrics, 106(6), 1380-1386. https://doi. org/10.1542/peds.106.6.1380

Baumrind, D. (1978). Parental disciplinary patterns and social competence in children. Youth \& Society, 9(3), 239-267. https://doi. org/10.1177/0044118X7800900302

Berge, J. M., Wall, M., Bauer, K. W., ve NeumarkSztainer, D. (2010). Parenting characteristics in the home environment and adolescent overweight: a latent class analysis. Obesity, 18(4), 818-825. https://doi.org/10.1038/oby.2009.324

Berge, J. M., Wall, M., Loth, K. ve Neumark-Sztainer, D. (2010). Parenting style as a predictor of adolescent weight and weight-related behaviors. Journal of Adolescent Health, 46(4), 331-338. https://doi. org/10.1016/j.jadohealth.2009.08.004

Bergmeier, H., Skouteris, H., Horwood, S., Hooley, M. ve Richardson, B. (2014). Associations between child temperament, maternal feeding practices and child body mass index during the preschool years: a systematic review of the literature. Obesity Reviews, 15(1), 9-18. https://doi.org/10.1111/obr.12066

Bergmeier, H., Skouteris, H., Horwood, S., Hooley, M. ve Richardson, B. (2013). Child temperament and maternal predictors of preschool children's eating and body mass index. A prospective study. Appetite, 74, 125-132. https://doi.org/10.1016/j. appet.2013.12.006

Birch, L. L., \& Davison, K. K. (2001). Family environmental factors influencing the developing behavioral controls of food intake and childhood overweight. Pediatric Clinics, 48(4), 893-907. https://doi.org/10.1016/S0031-3955(05)70347-3

Birch, L. L. ve Fisher, J. O. (1998). Development of eating behaviors among children and adolescents. Pediatrics, 101(Supplement 2), 539-549.

Birch, L. L., Fisher, J. O., Grimm-Thomas, K., Markey, C. N., Sawyer, R. ve Johnson, S. L. (2001). Confirmatory factor analysis of the Child Feeding Questionnaire: A measure of parental attitudes, beliefs and practices about child feeding and obesity proneness. Appetite, 36(3), 201-210. https://doi.org/10.1006/appe.2001.0398

Birch, L. L., Fisher, J. O. ve Davison, K. K. (2003). Learning to overeat: maternal use of restrictive feeding practices promotes girls' eating in the absence of hunger. The American Journal of Clinical Nutrition, 78(2), 215-220. https://doi. org/10.1093/ajen/78.2.215

Black, M. M., ve Aboud, F. E. (2011). Responsive feeding is embedded in a theoretical framework of responsive parenting. The Journal of Nutrition, 141(3), 490494. https://doi.org/10.3945/jn.110.129973

Blissett, J. ve Haycraft, E. (2008). Are parenting style and controlling feeding practices related?. Appetite, 50(2-3), 477-485. https://doi.org/10.1016/j. appet.2007.10.003

Blissett, J., Meyer, C., ve Haycraft, E. (2006). Maternal and paternal controlling feeding practices with male and female children. Appetite, 47(2), 212219. https://doi.org/10.1016/j.appet.2006.04.002 
Brown, K. A., Ogden, J., Vögele, C. ve Gibson, E. L. (2008). The role of parental control practices in explaining children's diet and BMI. Appetite, 50(2-3), 252-259. https://doi.org/10.1016/j. appet.2007.07.010

Bocca, G., Corpeleijn, E., Stolk, R.P., ve Sauer, P.J.J. (2012). Results of a multidisciplinary treatment program in 3-year old to 5-year-old overweight or obese children a randomized controlled clinical trial. Archives of Pediatrics \& Adolescent Medicine, 166, 1109-1115. https://doi.org/10.1001/ archpediatrics.2012.1638

Boots, S. B., Tiggemann, M., Corsini, N. ve Mattiske, J. (2015). Managing young children's snack food intake. The role of parenting style and feeding strategies. Appetite, 92, 94-101. https://doi. org/10.1016/j.appet.2015.05.012

Braden, A., Rhee, K., Peterson, C. B., Rydell, S. A., Zucker, N. ve Boutelle, K. (2014). Associations between child emotional eating and general parenting style, feeding practices, and parent psychopathology. Appetite, 80, 35-40. https://doi. org/10.1016/j.appet.2014.04.017

Bronfenbrenner, U. (1986). Ecology of the family as a context for human development: Research perspectives. Developmental Psychology, 22(6), 723742. https://doi.org/10.1037/0012-1649.22.6.723

Bronfenbrenner, U. (1989). Annals of Child Development. R. Vasta (Ed.), Ecological Systems Theory (6. Bask1, s. 187-251) içinde. JAI, Greenwich.

Brotman, L.M., Dawson-McClure, S., Huang, K.Y., Theise, R., Kamboukos, D., Wang, J., ve Ogedegbe, G. (2012). Early childhood family intervention and long-term obesity prevention among high-risk minority youth. Pediatrics, 129, 621-628. https:// doi.org/10.1542/peds.2011-1568

Camc1, N., Baş, M. ve Büyükkaragöz, A. H. (2014). The psychometric properties of the child Feeding Questionnaire (CFQ) in Turkey. Appetite, 78, 4954. https://doi.org/10.1016/j.appet.2014.03.009

Campbell, K., Andrianopoulos, N., Hesketh, K., Ball, K., Crawford, D., Brennan, L., Corsini, N. ve Timperio, A. (2010). Parental use of restrictive feeding practices and child BMI z-score. A 3-year prospective cohort study. Appetite, 55(1), 84-88. https://doi.org/10.1016/j.appet.2010.04.006

Cardel, M., Willig, A. L., Dulin-Keita, A., Casazza, K., Beasley, T. M. ve Fernández, J. R. (2012). Parental feeding practices and socioeconomic status are associated with child adiposity in a multi-ethnic sample of children. Appetite, 58(1), 347-353. https://doi.org/10.1016/j.appet.2011.11.005
Cassidy, J. (2008). The nature of child's ties. J. Cassidy ve P. R. Shaver (Ed.) Handbook of attachment: Theory, research, and clinical applications (2. Bask1, s. 3-22) içinde. (pp. 3-22). NY: The Guilford Press.

Cebeci, N. ve Güven, A. (2014). Does maternal obesity have an influence on feeding behavior of obese children?. Minerva Pediatrica, 67(6), 481-487.

Chang, L. Y., Mendelsohn, A. L., Fierman, A. H., Au, L. Y. ve Messito, M. J. (2017). Perception of child weight and feeding styles in parents of ChineseAmerican preschoolers. Journal of Immigrant and Minority Health, 19(2), 302-308. https://doi. org/10.1007/s10903-016-0541-9

Clark, H. R., Goyder, E., Bissell, P., Blank, L. ve Peters, J. (2007). How do parents' child-feeding behaviours influence child weight? Implications for childhood obesity policy. Journal of Public Health, 29(2), 132-141. https://doi.org/10.1093/pubmed/fdm012

Connell, L. E., ve Francis, L. A. (2014). Positive parenting mitigates the effects of poor selfregulation on body mass index trajectories from ages 4-15 years. Health Psychology, 33(8), 757764. https://doi.org/10.1037/hea0000014

Cooke, L. J., Wardle, J., Gibson, E. L., Sapochnik, M., Sheiham, A., ve Lawson, M. (2004). Demographic, familial and trait predictors of fruit and vegetable consumption by pre-school children. Public Health Nutrition, 7(2), 295-302. https://doi.org/10.1079/ PHN2003527

Costa, F. S., Pino, D. L. ve Friedman, R. (2011). Caregivers' attitudes and practices: influence on childhood body weight. Journal of Biosocial Science, 43(3), 369-378. https://doi.org/10.1017/ S0021932011000022

Dai, H., Alsalhe, T. A., Chalghaf, N., Riccò, M., Bragazzi, N. L., \& Wu, J. (2020). The global burden of disease attributable to high body mass index in 195 countries and territories, 1990-2017: An analysis of the Global Burden of Disease Study. PLoS Medicine, 17(7), 1-19. https://doi. org/10.1371/journal.pmed.100319

Darling, N. ve Steinberg, L. (1993). Parenting style as context: An integrative model. Psychological Bulletin, 113(3), 487-496.

De Bourdeaudhuij, I., Te Velde, S. J., Maes, L., Perez-Rodrigo, C., De Almeida, M. veBrug, J. (2009). General parenting styles are not strongly associated with fruit and vegetable intake and social-environmental correlates among 11-year-old children in four countries in Europe. Public Health Nutrition, 12(2), 259-266. https://doi.org/10.1017/ S1368980008002930 
Dev, D. A., McBride, B. A., Fiese, B. H., Jones, B. L., Cho H. ve STRONG Kids Research Team (2013). Risk factors for overweight/obesity in preschool children: an ecological approach. Childhood Obesity, 9(5), 399-408. https://doi.org/10.1089/ chi.2012.0150

Enten, R. S., ve Golan, M. (2008). Parenting styles and weight-related symptoms and behaviors with recommendations for practice. Nutrition Reviews, $66(2), \quad 65-75 . \quad \mathrm{https} / / /$ doi.org/10.1111/j.17534887.2007.00009.x

Erdem, S., Özel, H. G., Çınar, Z. ve Işıkhan, S. Y. (2017). Farklı sosyoekonomik düzeye sahip çocuklarda ailenin beslenme tutum ve davranışlarının çocuğun beslenme durumuna etkisi. Beslenme ve Diyet Dergisi, 45(1), 3-11.

Eschenbeck, H., Kohlmann, C. W., Dudey, S. ve Schürholz, T. (2009). Physician-diagnosed obesity in German 6-to 14-year-olds. Obesity Facts, 2(2), 67-73. https://doi.org/10.1159/000209987

Faith, M. S., Berkowitz, R. I., Stallings, V. A., Kerns, J., Storey, M. ve Stunkard, A. J. (2004a). Parental feeding attitudes and styles and child body mass index: Prospective analysis of a gene-environment interaction. Pediatrics, 114(4), 429-436. https:// doi.org/10.1542/peds.2003-1075-L

Faith, M. S., Scanlon, K. S., Birch, L. L., Francis, L. A. ve Sherry, B. (2004b). Parent-child feeding strategies and their relationships to child eating and weight status. Obesity Research, 12(11), 17111722. https://doi.org/10.1038/oby.2004.212

Farrow, C. V. ve Blissett, J. (2008). Controlling feeding practices: cause or consequence of early child weight?. Pediatrics, 121(1), 164-169. https://doi. org/10.1542/peds.2006-3437

Farrow, C., Blissett, J. ve Haycraft, E. (2011). Does child weight influence how mothers report their feeding practices?. International Journal of Pediatric Obesity, 6(3-4), 306-313. https://doi.org/10.3109/1747 7166.2011 .575160

Finkelstein, E.A., Ruhm, C.J., ve Kosa, K.M. (2005). Economic causes and consequences of obesity. Annual Review of Public Health, 26, 239-257. https://doi.org/10.1146/annurev. publhealth.26.021304.144628

Fisher, J. O. ve Birch, L. L., (1999a). Restricting access to foods and children's eating. Appetite, 32(3), 405-419. https://doi.org/10.1006/appe.1999.0231

Fisher, J. O. ve Birch, L. L. (1999b). Restricting access to palatable foods affects children's behavioral response, food selection, and intake. The American Journal of Clinical Nutrition, 69(6), 1264-1272. https://doi.org/10.1093/ajen/69.6.1264
Fitzgibbon, M.L., Stolley, M.R., Schiffer, L., Kong, A., Braunschweig, C.L., Gomez-Perez, S.L., . . . ve Dyer, A.R. (2013). Family-based hiphop to health: outcome results. Obesity (Silver Spring), 21(2), 274-283. https://doi.org/10.1002/ oby. 20269

Foster, B. A., Farragher, J., Parker, P., ve Sosa, E. T. (2015). Treatment interventions for early childhood obesity: a systematic review. Academic Pediatrics, 15(4), 353-361. https://doi.org/10.1016/j. acap.2015.04.037

Francis, L. A., Hofer, S. M. ve Birch, L. L. (2001). Predictors of maternal child-feeding style: maternal and child characteristics. Appetite, 37(3), 231-243. https://doi.org/10.1006/appe.2001.0427

Francis, L. ve Susman, E. (2009). Self-regulation and rapid weight gain in children from age 3 to 12 years. Archives of Pediatrics \& Adolescent Medicine, 163(4), 297-302. https://doi.org/10.1001/ archpediatrics.2008.579

Fraser, J., Skouteris, H., McCabe, M., Ricciardelli, L. A., Milgrom, J., ve Baur, L. A. (2011). Paternal influences on children's weight gain: a systematic review. Fathering, 9(3), 252-267.

Fuemmeler, B. F., Yang, C., Costanzo, P., Hoyle, R. H., Siegler, I. C., Williams, R. B., ve Østbye, T. (2012). Parenting styles and body mass index trajectories from adolescence to adulthood. Health Psychology, 31(4), 441-449. https://doi. org/10.1037/a0027927

Gahagan, S. (2012). The development of eating behavior-biology and context. Journal of Developmental and Behavioral Pediatrics, 33(3), 261. https://doi. org/10.1097/DBP.0b013e31824a7baa

Galloway, A. T., Fiorito, L. M., Francis, L. A. ve Birch, L. L. (2006). 'Finish your soup': counterproductive effects of pressuring children to eat on intake and affect. Appetite, 46(3), 318-323. https://oi. org/10.1016/j.appet.2006.01.019

Gibson, L. Y., Byrne, S. M., Davis, E., Blair, E., Jacoby, P. ve Zubrick, P. (2007). The role of family and maternal factors in childhood obesity. Medicine and the Community, 186(11), 591-595. https://doi. org/10.5694/j.1326-5377.2007.tb01061.x

Golan, M., ve Bachner-Melman, R. (2011). Self-regulation and the management of childhood obesity. Journal of Community Medicine and Health Education, 1(107), 2161-0711. https://doi.org/10.4172/ jcmhe. 1000107

Golan, M. ve Crow, S. (2004). Parents are key players in the prevention and treatment of weight-related problems. Nutrition Reviews, 62(1), 39-50. https:// doi.org/10.1111/j.1753-4887.2004.tb00005.x 
Gregory, J. E., Paxton, S. J. ve Brozovic, A. M. (2010). Pressure to eat and restriction are associated with child eating behaviours and maternal concern about child weight, but not child body mass index, in 2-to 4-year-old children. Appetite, 54(3), 550556. https://doi.org/10.1016/j.appet.2010.02.013

Grolnick, W. ve Farkas, M. (2002). Parenting and the development of children's self-regulation. M. H. Bornstein, (Ed.), Handbook of Parenting (5. baskl) içinde (89-110). London: Lawrence Erlbaum Associates.

Grusec, J. E. (2002). Parental socialization and children's acquisition of values. M. H. Bornstein (Ed.), Handbook of parenting:Practical issues in parenting (5. Bask1, s.143-167) içinde.Mahwah, NJ: Erlbaum.

Gubbels, J. S., Kremers, S. P., Stafleu, A., de Vries, S. I., Goldbohm, R. A., Dagnelie, P. C., de Vries, N., K., van Buuren, S. ve Thijs, C. (2011). Association between parenting practices and children's dietary intake, activity behavior and development of body mass index: the KOALA Birth Cohort Study. International Journal of Behavioral Nutrition and Physical Activity, 8(1), 1-13. https://doi. org/10.1186/1479-5868-8-18.

Haycraft, E. L. ve Blissett, J. M. (2008). Maternal and paternal controlling feeding practices: reliability and relationships with BMI. Obesity, 16(7), 15521558. https://doi.org/10.1038/oby.2008.238

Haycraft, E., Farrow, C., Meyer, C., Powell, F. ve Blissett, J. (2011). Relationships between temperament and eating behaviours in young children. Appetite, 56(3), 689-692. https://doi.org/10.1016/j.appet.2011.02.005

Hendy, H. M., Williams, K. E., Camise, T. S., Eckman, N., ve Hedemann, A. (2009). The Parent Mealtime Action Scale (PMAS). Development and association with children's diet and weight. $A p$ petite, 52(2), 328-339. https://doi.org/10.1016/j. appet.2008.11.003

Hennessy, E., Hughes, S. O., Goldberg, J. P., Hyatt, R. R., ve Economos, C. D. (2010). Parent behavior and child weight status among a diverse group of underserved rural families. Appetite 54, 369-377. https://doi.org/10.1016/j.appet.2010.01.004

Hidalgo-Mendez, J., Power, T. G., Fisher, J. O., O’Connor, T. M. ve Hughes, S. O. (2019). Child weight status and accuracy of perceived child weight status as predictors of Latina mothers' feeding practices and styles. Appetite, 142. https://doi.org/10.1016/j. appet.2019.104387

Hughes, S. O., Power, T. G., Fisher, J. O., Mueller, S. ve Nicklas, T. A. (2005). Revisiting a neglected construct: parenting styles in a child-feeding context,
Appetite, 44(1), 83-92. https://doi.org/10.1016/j. appet.2004.08.007

Hughes, S. O., Power, T. G., O’Connor, T. M., Orlet Fisher, J. ve Chen, T. A. (2016). Maternal feeding styles and food parenting practices as predictors of longitudinal changes in weight status in Hispanic preschoolers from low-income families. Journal of Obesity. https://doi.org/10.1155/2016/7201082

Jansen, P. W., de Barse, L. M., Jaddoe, V. W., Verhulst, F. C., Franco, O. H., ve Tiemeier, H. (2017). Bi-directional associations between child fussy eating and parents' pressure to eat: Who influences whom? Physiology \& Behavior, 176, 101-106. https://doi. org/10.1016/j.physbeh.2017.02.015

Jansen, P. W., Roza, S. J., Jaddoe, V. W., Mackenbach, J. D., Raat, H., Hofman, A., ... Tiemeier, H. (2012). Children's eating behavior, feeding practices of parents and weight problems in early childhood: results from the population-based Generation $\mathrm{R}$ Study. The International Journal of Behavioral Nutrition and Physical Activity, 9, 130-141. https:// doi.org/10.1186/1479-5868-9-130

Johnson, S. L. ve Birch, L. L. (1994). Parents' and children's adiposity and eating style. Pediatrics, 94(5), 653-661.

Johnson, R., Welk, G., Saint-Maurice, P. F. ve Ihmels, M. (2012). Parenting styles and home obesogenic environments. International Journal of Environmental Research and Public Health, 9(4), 1411-1426. https://doi.org/10.3390/ijerph9041411

Kakinami, L., Barnett, T. A., Séguin, L., ve Paradis, G. (2015). Parenting style and obesity risk in children. Preventive Medicine, 75, 18-22. https://doi. org/10.1016/j.ypmed.2015.03.005

Khandpur, N., Blaine, R. E., Fisher, J. O., ve Davison, K. K. (2014). Fathers' child feeding practices: A review of the evidence. Appetite, 78, 110-121. https://doi.org/10.1016/j.appet.2014.03.015

Kremers, S. P., Brug, J., de Vries, H. ve Engels, R. C. (2003). Parenting style and adolescent fruit consumption. Appetite, 4l(1), 43-50. https://doi. org/10.1016/S0195-6663(03)00038-2

Lane, S. P., Bluestone, C., ve Burke, C. T. (2013). Trajectories of BMI from early childhood through early adolescence: SES and psychosocial predictors. British Journal of Health Psychology, 18(1), 66-82. https://doi.org/10.1111/j.2044-8287.2012.02078.x

Lee, Y., Mitchell, D. C., Smiciklas-Wright, H. ve Birch, L. L. (2001). Diet quality, nutrient intake, weight status, and feeding environments of girls meeting or exceeding recommendations for total dietary fat of the American Academy of Pediatrics. Pediatrics, 107(6). https://doi.org/10.1542/peds.107.6.e95 
Leung, C. Y., Lumeng, J. C., Kaciroti, N. A., Chen, Y. P., Rosenblum, K. ve Miller, A. L. (2014). Surgency and negative affectivity, but not effortful control, are uniquely associated with obesogenic eating behaviors among low-income preschoolers. Appetite, 78, 139146. https://doi.org/10.1016/j.appet.2014.03.025

Lev-Ari, L. ve Zohar, A. H. (2013). Nothing gained: An explorative study of the long-term effects of perceived maternal feeding practices on women's and men's adult BMI, body image dissatisfaction, and disordered eating. International Journal of Psychology, 48(6), 1201-1211. https://doi.org/10.108 0/00207594.2013.779378

Liszewska, N., Scholz, U., Radtke, T., Horodyska, K. ve Luszczynska, A. (2018). Bi-directional associations between parental feeding practices and children's body mass in parent-child dyads. $A p$ petite, 129, 192-197. https://doi.org/10.1016/j.appet.2018.07.011

Lohaus, A., Vierhaus, M. ve Ball, J. (2009). Parenting styles and health-related behavior in childhood and early adolescence: Results of a longitudinal study. The Journal of Early Adolescence, 29(4), 449-475. https://doi.org/10.1177/0272431608322954

Loth, K. A. (2016). Associations between food restriction and pressure-to-eat parenting practices and dietary intake in children: a selective review of the recent literature. Current Nutrition Reports, 5(1), 61-67. https://doi.org/10.1007/s13668-016-0154-x

Maccoby, E. E., ve Martin, J. A. (1983). Socialization in the context of the family: parent-child interaction. P. H. Mussen ve E. M. Heatherington (Ed.), Handbook of Child Psychology: Socialization, Personality, and Social Development (4. baskı) içinde (1102). New York: Wiley.

Magarey, A. M., Daniels, L. A., Boulton, T. J. ve Cockington, R. A. (2003). Predicting obesity in early adulthood from childhood and parental obesity. International Journal of Obesity, 27(4), 505-513.

Maiano, C., Lepage, G., Aimé, A., Bayard, C., Dansereau-Trahan, É., Granger, L., ... Morin, A. J. (2018). Perceived weight-related victimization and physical activity outcomes among adolescents with overweight and obesity: Indirect role of perceived physical abilities and fear of enacted stigma. Psychology of Sport and Exercise, 34, 70-78. https:// doi.org/10.1016/j.psychsport.2017.08.007

Mallan, K. M., Daniels, L. A., Nothard, M., Nicholson, J. M., Wilson, A., Cameron, C. M., ... ve Thorpe, K. (2014). Dads at the dinner table. A cross-sectional study of Australian fathers' child feeding perceptions and practices. Appetite, 73, 40-44. https://doi. org/10.1016/j.appet.2013.10.006
Mallan, K. M., Nothard, M., Thorpe, K., Nicholson, J. M., Wilson, A., Scuffham, P. A., ve Daniels, L. A. (2013). The role of fathers in child feeding: perceived responsibility and predictors of participation. Child: Care, health and development, 40(5), 715-722. https://doi.org/10.1111/cch.12088

May, A. L., Donohue, M., Scanlon, K. S., Sherry, B., Dalenius, K., Faulkner, P. ve Birch, L. L. (2007). Child-feeding strategies are associated with maternal concern about children becoming overweight, but not children's weight status. Journal of the American Dietetic Association, 107(7), 1167-1174. https://doi.org/10.1016/j. jada.2007.04.009

Min, J., Wang, V. H., Xue, H., Mi, J. ve Wang, Y. (2017). Maternal perception of child overweight status and its association with weight-related parenting practices, their children's health behaviours and weight change in China. Public Health Nutrition, 20(12), 2096-2103. https://doi.org/10.1017/ S1368980017001033

Nemet, D., Geva, D., Pantanowitz, M., Igbaria, N., Meckel, Y., ve Eliakim, A. (2013). Long term effects of a health promotion intervention in low socioeconomic Arab- Israeli kindergartens. $\mathrm{BMCPe}$ diatrics, 13(1), 1-7. https://doi.org/10.1186/14712431-13-45

Niemeier, B.S., Hektner, J.M., ve Enger, K.B. (2012). Parent participation in weight-related health interventions for children and adolescents: A systematic review and metaanalysis. Preventive Medicine, 55(1), 3-13. https://doi.org/10.1016/j. ypmed.2012.04.021

Ogden, J., Reynolds, R. ve Smith, A. (2006). Expanding the concept of parental control: A role for overt and covert control in children's snacking behaviour? Appetite, 47(1), 100-106. https://doi.org/10.1016/j. appet.2006.03.330

Olvera, N. ve Power, T. G. (2009). Brief report: parenting styles and obesity in Mexican American children: A longitudinal study. Journal of Pediatric Psychology, 35(3), 243-249. https://doi.org/10.1093/jpepsy/jsp071

Olvera-Ezzell, N., Power, T. G. ve Cousins, J. H. (1990). Maternal socialization of children's eating habits: Strategies used by obese Mexican-American mothers. Child Development, 61(2), 395-400. https:// doi.org/10.1111/j.1467-8624.1990.tb02785.x

Özdoğan, Y., Balaban, S. ve Uçar, A. (2018). Annelerin çocuk besleme uygulamaları ve çocukların yemek yeme davranışları. Nevşehir Bilim ve Teknoloji Dergisi, 7(1), 1-13. https://doi.org/10.17100/ nevbiltek.326672 
Öztora, S., Hatipoğlu, S., Barutçugil, M. B., Salihoğlu, B., Yıldırım, R. ve Şevketoğlu, E. (2006). İlköğretim çağındaki çocuklarda obezite prevalansının belirlenmesi ve risk faktörlerinin araştırılması. Bakırköy Tıp Dergisi, 2(1), 11-14.

Öztürk, A. ve Aktürk, S. (2011). İlköğretim öğrencilerinde obezite prevalansı ve ilişkili risk faktörleri. TSK Koruyucu Hekimlik Bülteni, 10(1), 53-60. https://doi.org/10.5455/PMB.20101119041916

Pace, U., Aiello, F., ve Zappulla, C. (2019). Childhood obesity: the relationship between negative emotionality, emotion regulation, and parenting styles. Journal of Child and Family Studies, 28(8), 22722279. https://doi.org/10.1007/s10826-019-01443-3

Patrick, H. ve Nicklas, T. A. (2005). A review of family and social determinants of children's eating patterns and diet quality. Journal of the American College of Nutrition, 24(2), 83-92. https://doi.org/1 0.1080/07315724.2005.10719448

Pearce, J., Taylor, M. A. ve Langley-Evans, S. C. (2013). Timing of the introduction of complementary feeding and risk of childhood obesity: A systematic review. International Journal of Obesity, 37(10), 1295-1306. https://doi.org/10.1038/ijo.2013.99

Pesch, M. H., Appugliese, D. P., Kaciroti, N., Rosenblum, K. L., Miller, A. L. ve Lumeng, J. C. (2016). Maternal encouragement and discouragement: Differences by food type and child weight status. Appetite, 101, 15-22. https://doi.org/10.1016/j.appet.2016.02.146

Pinquart, M. (2017a). Associations of parenting dimensions and styles with externalizing problems of children and adolescents: An updated meta-analysis. Developmental psychology, 53(5), 873-932. https://doi.org/10.1037/dev0000295

Pinquart, M. (2017b). Associations of parenting dimensions and styles with internalizing symptoms in children and adolescents: A meta-analysis. Marriage \& Family Review, 53(7), 613-640. https:// doi.org/10.1080/01494929.2016.1247761

Powell, F., Farrow, C., Meyer, C. ve Haycraft, E. (2018). The stability and continuity of maternally reported and observed child eating behaviours and feeding practices across early childhood. International Journal of Environmental Research and Public Health, 15(5), 1017-1031. https://doi.org/10.3390/ ijerph15051017

Power, T. G. (2013). Parenting dimensions and styles: A brief history and recommendations for future research. Childhood Obesity, 9, 14-21. https://doi. org/10.1089/chi.2013.0034

Powers, S. W., Chamberlin, L. A., Van Schaick, K. B., Sherman, S. N. ve Whitaker, R. C. (2006). Mater- nal feeding strategies, child eating behaviors, and child BMI in low-income African-American preschoolers. Obesity, 14(11), 2026-2033. https://doi. org/10.1038/oby.2006.237

Pulley, C., Galloway, A. T., Webb, R. M., ve Payne, L. O. (2014). Parental child feeding practices: How do perceptions of mother, father, sibling, and self vary?. Appetite, 80, 96-102. https://doi. org/10.1016/j.appet.2014.05.001

Reilly, J. J., Methven, E., McDowell, Z. C., Hacking, B., Alexander, D., Stewart, L. ve Kelnar, C. J. (2003). Health consequences of obesity. Archives of Disease in Childhood, 88(9), 748-752. http://dx.doi. org/10.1136/adc.88.9.748

Reilly, J. ve Kelly, J. (2011). Long-term impact of overweight and obesity in childhood and adolescence on morbidity and premature mortality in adulthood: Systematic review. International Journal of Obesity, 35, 891-898. https://doi.org/10.1038/ ijo. 2010.222

Rhee, K. E., Lumeng, J. C., Appugliese, D. P., Kaciroti, N. ve Bradley, R. H. (2006). Parenting styles and overweight status in first grade. Pediatrics, 117(6), 2047-2054. https://doi.org/10.1542/peds.20052259

Rhee, K. (2008). Childhood overweight and the relationship between parent behaviors, parenting style, and family functioning. The $A N$ NALS of the American Academy of Political and Social Science, 615(1), 11-37. https://doi. org/10.1177/0002716207308400

Rodgers, R. F., Paxton, S. J., Massey, R., Campbell, K. J., Wertheim, E. H., Skouteris, H. ve Gibbons, K. (2013). Maternal feeding practices predict weight gain and obesogenic eating behaviors in young children: a prospective study. International Journal of Behavioral Nutrition and Physical Activity, 10(1), 24-33. https://doi.org/10.1186/1479-5868-10-24

Rollins, B. Y., Savage, J. S., Fisher, J. O., ve Birch, L. L. (2016). Alternatives to restrictive feeding practices to promote self-regulation in childhood: a developmental perspective. Pediatric Obesity, 11(5), 326332. https://doi.org/10.1111/ijpo.12071

Rothbart, M. K., Ahadi, S. A. ve Evans, D. E. (2000). Temperament and personality: origins and outcomes. Journal of Personality and Social Psychology, 78(1), 122-135. https://doi.org/10.1037/00223514.78 .1 .122

Russell, C. G., Worsley, A., ve Campbell, K. J. (2015). Strategies used by parents to influence their children's food preferences. Appetite, 90, 123-130. https://doi.org/10.1016/j.appet.2015.02.038 
Savage, J. S., Fisher, J. O. ve Birch, L. L. (2007). Parental influence on eating behavior: conception to adolescence. The Journal of Law, Medicine \& Ethics, 35(1), 22-34. https://doi.org/10.1111/j.1748720X.2007.00111.x

Scaglioni, S., Salvioni, M. ve Galimberti, C. (2008). Influence of parental attitudes in the development of children eating behaviour. British Journal of Nutrition, 99(1), 22-25. https://doi.org/10.1017/ S0007114508892471

Scott-Sheldon, L. A., Hedges, L. V., Cyr, C., Young-Hyman, D., Khan, L. K., Magnus, M., ... ve Schwartz, M. B. (2020). Childhood Obesity Evidence Base Project: A systematic review and meta-analysis of a new taxonomy of intervention components to improve weight status in children $2-5$ years of age, 2005-2019. Childhood Obesity, 16(S2), 221-248. https://doi.org/10.1089/chi.2020.0139

Shloim, N., Edelson, L. R., Martin, N., ve Hetherington, M. M. (2015). Parenting styles, feeding styles, feeding practices, and weight status in 4-12 yearold children: A systematic review of the literature. Frontiers in Psychology, 6, 1-20.https://doi. org/10.3389/fpsyg.2015.01849

Spera, C. (2005). A review of the relationship among parenting practices, parenting styles, and adolescent school achievement. Educational Psychology Review, 17(2), 125-146. https://doi.org/10.1007/ s10648-005-3950-1

Stark, L.J., Spear, S., Boles, R., Kuhl, E., Ratcliff, M., Scharf, C., . . . ve Rausch, J. (2011). A pilot randomized controlled trial of a clinic and home-based behavioral intervention to decrease obesity in preschoolers. Obesity (Silver Spring), 19, 134-141. https://doi.org/10.1038/oby.2010.87

Storch, E. A., Milsom, V. A., DeBraganza, N., Lewin, A. B., Geffken, G. R. ve Silverstein, J. H. (2006). Peer victimization, psychosocial adjustment, and physical activity in overweight and at-risk-foroverweight youth. Journal of Pediatric Psychology, 32(1), 80-89. https://doi.org/10.1093/jpepsy/ jisj 113

Tschann, J. M., Gregorich, S. E., Penilla, C., Pasch, L. A., de Groat, C. L., Flores, E., et al.(2013). Parental feeding practices in Mexican American families. Initial test of an expanded measure. International Journal of Behavioral Nutrition and Physical Activity, 10(1), 1-8. https://doi.org/10.1186/1479-5868-10-6

Türkiye Beslenme ve Sağl1k Araştırması. (2014). Beslenme durumu ve alışkanlıklarının değerlendirilmesi sonuç raporu. SAGEM. http://www.sagem. gov.tr/TBSA_Beslenme_Yayini.pdf
Türkiye Çocukluk Çağı (İlkokul 2. Sinıf Öğrencileri) Şişmanlık Araştırması (COSI-TUR). (2016). Sağlık Bakanlığı, Halk Sağlığı Genel Müdürlüğü, Milli Eğitim Bakanlığı, Dünya Sağlık Örgütü Avrupa Bölge Ofisi, Sağlık Bakanlığı. Yayın No: 1080, Ankara 2017.

Turan, T., Ceylan, S. S., Çetinkaya, B. ve Altundağ, S. (2009). Meslek lisesi öğrencilerinin obezite sıklığının ve beslenme alışkanlıklarının incelenmesi. TSK Koruyucu Hekimlik Bülteni, 8(1), 5-12.

Uzun, N. (2015). Ergenlerde sağlıklı yaşam biçimi davranışlart, ebeveyn kontrolü ve depresyon ile obezitenin ilişkisi: Obezite için koruyucu ve risk faktörleri. Yayınlanmamış yüksek lisans tezi, Adnan Menderes Üniversitesi, Aydın.

Van den Heuvel, M., Chen, Y., Abdullah, K., Maguire, J. L., Parkin, P. C., Birken, C. S. ve TARGet Kids! Collaboration. (2017). The concurrent and longitudinal associations of temperament and nutritional risk factors in early childhood. Pediatric Obesity, 12(6), 431-438. https://doi.org/10.1111/ ijpo. 12161

Vollmer, R. L., ve Mobley, A. R. (2013). Parenting styles, feeding styles, and their influence on child obesogenic behaviors and body weight. A review. Appetite, 71, 232-241. https://doi.org/10.1016/j. appet.2013.08.015

Wake, M., Nicholson, J. M., Hardy, P., ve Smith, K. (2007). Preschooler obesity and parenting styles of mothers and fathers: Australian national population study. Pediatrics, 120(6), 1520-1527. https://doi. org/10.1542/peds.2006-3707

Wang, Y. ve Lobstein, T. I. M. (2006). Worldwide trends in childhood overweight and obesity. International Journal of Pediatric Obesity, 1(1), 11-25. https:// doi.org/10.1080/17477160600586747

Wardle, J., Sanderson, S., Guthrie, C. A., Rapoport, L., ve Plomin, R. (2002). Parental feeding style and the inter-generational transmission of obesity risk. Obesity Research, 10(6), 453-462. https://doi. org/10.1038/oby.2002.63

Webber, L., Cooke, L., Hill, C. ve Wardle, J. (2010). Child adiposity and maternal feeding practices: A longitudinal analysis. The American Journal of Clinical Nutrition, 92(6), 1423-1428. https://doi. org/10.3945/ajen.2010.30112

Webber, L., Hill, C., Cooke, L., Carnell, S. ve Wardle, J. (2010). Associations between child weight and maternal feeding styles are mediated by maternal perceptions and concerns. European Journal of Clinical Nutrition, 64(3), 259-265. https://doi. org/10.1038/ejen.2009.146 
Weihrauch-Blüher, S., ve Wiegand, S. (2018). Risk factors and implications of childhood obesity. Current Obesity Reports, 7(4), 254-259. https://doi. org/10.1007/s13679-018-0320-0

Weinfield, N., Sroufe, A., Egeland, B., ve Carlson, E. (2008). Individual differences in infant-caregiver attachment: Conceptual and empirical aspects of security. J. Cassidy \& P. R. Shaver (Ed.) Handbook of attachment: Theory, research, and clinical applications (2. Bask1, s. 78-101) içinde. NY: The Guilford Press.

Withrow, D., ve Alter, D. (2010). The economic burden of obesity world-wide: A systematic review of the direct costs of obesity. Obesity Review, 12, 131-141. https://doi.org/10.1111/j.1467-789X.2009.00712.X

Wong, T. K., Konishi, C., ve Kong, X. (2021). Parenting and prosocial behaviors: A meta-analysis. Social Development.30, 343-373. https://doi. org/10.1111/sode. 12481

World Health Organization (Dünya Sağl1k Örgütü). (2020). Obesity and overweight fact sheet. 2016. WHO. https://www.who.int/news-room/factsheets/detail/obesity-and-overweight

Wu, T., Dixon, W. E., Dalton, W. T., Tudiver, F. ve Liu, X. (2011). Joint effects of child temperament and maternal sensitivity on the development of childhood obesity. Maternal and Child Health Journal, 15(4), 469-477. https://doi.org/10.1007/s10995010-0601-z

Yavuz, H. M., van Ijzendoorn, M. H., Mesman, J., ve van der Veek, S. (2015). Interventions aimed at reducing obesity in early childhood: A meta-analysis of programs that involve parents. Journal of Child Psychology and Psychiatry, 56(6), 677-692. https://doi.org/10.1111/jcpp.12330

Yavuz, H. M., Korucu, I., ve Selcuk, B., (2022). Temperament and social development. P. K. Smith ve C. H. Hart (Ed.), Wiley-Blackwell handbook of childhood social development (3. Bask1) içinde. West Sussex, UK: Wiley-Blackwell.

Yavuz, H. M. ve Selcuk, B. (2018). Predictors of obesity and overweight in preschoolers: the role of parenting styles and feeding practices. Appetite, 120, 491499. https://doi.org/10.1016/j.appet.2017.10.001

Young, K.M., Northern, J., Lister, K.M., Drummond, J.A., ve O'Brien, W. (2007). A meta-analysis of family-behavioral weight-loss treatments for children. Clinical Psychology Review, 27(2), 240-249. https://doi.org/10.1016/j.cpr.2006.08.003

Yücel, O., Kinik, S. T. ve Aka, S. (2011). Diagnosis of a trend towards obesity in preschool children: a longitudinal study. European Journal of Pediatrics, 170(6), 751-756. https://doi.org/10.1007/s00431$010-1343-\mathrm{z}$
Zhou, Z., SooHoo, M., Zhou, Q., Perez, M. ve Liew, J. (2019). Temperament as Risk and Protective Factors in Obesogenic Eating: Relations Among Parent Temperament, Child Temperament, and Child Food Preference and Eating. The Journal of Genetic Psychology, 180(1), 75-79. https://doi.org/10.10 $80 / 00221325.2019 .1575180$ 


\section{Summary \\ Precursors of Early Childhood Obesity: A Review}

\author{
Hatice Melis Müren ${ }^{1}$ \\ MEF University
}

\begin{abstract}
Introduction
Overweight/obesity in childhood years has become a worldwide epidemic in the current decades. World Health Organization (2018) reported that the prevalence of obesity in children worldwide tripled between 1975 and 2016 with more than 41 million children under the age of 5 being overweight/obese in 2016. Since obesity has been associated with a wide range of health problems (Eschenbeck et al., 2009; Maiano et al., 2018; Reilly \& Kelly, 2011; Storch et al., 2007) and its prevalence has increased excessively (Nutrition and Health Survey of Turkey, 2014; WHO, 2018), it is of great importance to identify the precursors of obesity and develop obesity intervention/prevention programs. Current review aims to compile national and international research regarding maternal child feeding behaviors and cognitions, parenting styles, and child temperament as important precursors of obesity. The main aim is to provide a review of the state of the art on childhood obesity to inform further research and obesity intervention programs.
\end{abstract}

\section{Child Feeding Behaviors and Obesity}

Parental child feeding behaviors play an important role in shaping children's early eating behaviors. Research has demonstrated that there is a significant relationship between children's body mass index (BMI) and parental child feeding behaviors (Hughes et al., 2005; Rhee ve ark., 2006; Yavuz \& Selçuk, 2018). Child feeding behaviors are commonly examined under three main categories: pressure to eat, restriction, and monitoring. Pressure to eat involves forcing the child to eat everything on his plate or pressuring the child to eat certain food. Restriction refers to restricting the child from consuming certain food either overtly or covertly. Overt restriction includes forbidding the child to eat certain food in a way that s/he can notice (e.g. verbally or by taking away the food). Covert restriction on the other hand, includes behaviors like not buying foods that the child should not consume and keeping these foods out of child's reach (Ogden, Reynolds, \& Smith, 2006). Lastly, monitoring involves keeping track of child's food intake.

\author{
Hatice Şule Yasin \\ Bilgi University
}

Among parental feeding behaviors especially restriction has detrimental effects on children's subsequent weight status (Faith et al., 2004b). As cross-sectional and longitudinal studies have shown, restriction is usually associated with higher child BMI (Clark et al., 2007; Patrick \& Nicklas, 2005; Shloim et al., 2015). It was argued that food restriction harmed children's self-regulation abilities and reliance on satiety cues (Birch et al., 2003; Savage \& Fischer, 2007). Therefore, children adopt unhealthy eating behaviors which may place them under higher risk of obesity.

Pressuring children to eat more or to consume certain types of food is generally associated with lower BMI in childhood (Hurley et al., 2011; Shloim et al., 2015). Although seems counterintuitive, there are possible theoretical explanations for this link. For example, it was argued that parental pressure to eat may cause negative attitudes about food and eating in general and therefore decrease child's general food consumption (Batsell et al., 2002; Galloway et al., 2006). Parental pressure to eat has also been associated with children's greater consumption of fruit/vegetables, indicating that pressuring may actually promote healthier diet (Bourcier et al., 2003). However, research also demonstrated that children who are pressured to eat, may reject to consume the pressured foods, and may have a preference for high-fat, calorie-dense snacks instead (Brown et al., 2008; Lee et al., 2001). Therefore, the findings in the literature did not show direct evidence even if pressure to eat has generally been associated with lower child BMI.

Monitoring is rather less studied compared to other child feeding behaviors . Most studies did not find a significant association between parental monitoring and child BMI (Shloim et al., 2015). However, some researchers suggested that monitoring may be beneficial for children to adopt healthy eating behaviors (Faith et al., 2004a; Gubbels et al. 2011). For example it was found that children make healthier food choices when they were informed that parents would know what they eat (Klesges et al., 1991). Moreover, longitudinal research confirms that parental monitoring may be asso-

Address for Correspondence: ${ }^{1}$ Asst. Prof. Hatice Melis Müren, MEF University, Faculty of Economics, Administrative and Social Sciences, Department of Psychology, Maslak, Sariyer / Istanbul

E-mail: murenm@mef.edu.tr 
ciated with lower BMI and healthier diet (Faith et al., 2004a; Gubbels et al., 2011). Yet, given the scarcity of studies, the results are not conclusive.

\section{Parenting Styles and Obesity}

Parenting styles refer to parental behaviors and attitudes towards the child and general emotional atmosphere in home environment (Darling \& Steinberg, 1993). Parenting styles are commonly examined under four main dimensions: authoritative, authoritarian, permissive, and neglecting parenting (Baumrind, 1978; Maccoby \& Martin, 1983). In this review, neglecting parenting was not included because of the scarcity of research based on its association with childhood obesity.

Authoritative parenting style is characterized by high parental demandingness and high warmth/responsiveness (Power, 2013) and is generally associated with lower BMI (Sleddens et al., 2011). When compared to authoritarian and permissive styles, authoritative parenting is related to increased consumption of healthy food and lower risk for obesity (Chen \& Kennedy, 2004; Kremers et al. , 2003). On the other hand, authoritarian parenting style, which involves high demandingness but low responsiveness to the child (Spera, 2005), is mostly found to be associated with children's low ability to self-regulate (Francis \& Susman, 2009; Grolnick \& Farkas, 2002), higher risk for obesity (Kakinami et al.,, 2015) and lower levels of positive health-related behavior such as good nutrition and physical activity (Lohaus et al., 2009).

Research about permissive parenting (high warmth/ responsiveness and low demandingness; Power, 2013), are less in quantity and the findings are not well-established. While some research cannot find a significant association with child BMI (Agras et al., 2004; Blissett \& Haycraft, 2008), some argue that permissive parenting may be a precursor of childhood obesity (Humenikova \& Gates, 2008; Olvera-Ezzell \& Power, 2009). Yet, other research suggests that it may promote a healthier diet in children in terms of more fruit/vegetable consumption (Berge et al., 2010; Kremers et al., 2003). The discrepancy in the findings may point out the importance of positive parenting behaviors, such that showing high levels of warmth/responsiveness to children may facilitate a healthier diet. However, further research needs to be conducted to explore the parental behavioral mechanisms affecting children's dietary intake and BMI.

\section{Maternal Cognitions on Child Weight and Obesity}

Besides maternal feeding practices, maternal cognitions that affect mothers' feeding may also play a crucial role in early childhood overweight/obesity. For instance, when parents are concerned about their child being overweight they tend to show more restrictive behaviors (Hidalgo-Mendez et al., 2019) and encourage their child to diet and do physical activity (Min et al., 2017). Similarly, when mothers think that their child is underweight, they pressure them to eat more (Gregory et al., 2010).

A crucial problem about maternal cognitions of children's weight status is that mothers are generally not aware that their children are overweight (Chamberlin et al., 2000; Carnell et al., 2005). In fact, in many cultures including Turkey, being chubby is considered as a health sign among children (Agaday1 et al., 2019; Savaşhan et al., 2015). Research confirms that mothers tend to not realize their children are overweight and they may nevertheless pressure their children to eat (Chang et al., 2017). Therefore, it is of greater importance to plan prevention programs and create awareness in parents about childhood obesity.

\section{Child Temperament and Childhood Obesity}

Parental child feeding behaviors, parenting styles and parental perceptions play a significant role in early childhood obesity, yet some children have a higher tendency to become overweight/obese. In-born temperamental characteristics of children may affect their eating behaviors, therefore create a risk factor for obesity (Anzman-Fransca et al., 2012). Research has examined temperamental characteristics in mainly three dimensions, which are positive and negative affectivity, and inhibitory control (Rothbart et al., 2000).

High level of negative affectivity was generally associated with higher risk for obesity in children (see Bergmeier et al., 2014 for a review). Research suggests that children who are high in negative affect are fed with unhealthy foods more by their mothers, and mothers tend to use food for soothing their children with negative affectivity (Agras et al., 2004; Stifter et al., 2011). This situation may have subsequent negative effects on children's eating, such that in following years they may have a tendency to eat more in response to negative emotions as opposed to satiety cues (Anzman-Frasca et al., 2012; Braden et al. 2014; Stifter et al., 2011).

Low levels of inhibitory control in children is pointed out as another risk factor for childhood obesity (see Anzman-Frasca et al., 2012 for a review). Children who have low inhibitory control tend to have difficulties in regulating their food intake. Especially when they are exposed to obesogenic environments in which high calorie dense foods are always accessible, these children may be under higher risk for obesity (Francis \& Susman, 2009; Johnson \& Birch, 1994). Research confirms that by showing children with higher inhibitory control tend to make healthier food choices, have healthier dietary 
and physical activity habits (Van den Heuvel et al., 2017; Zhou et al., 2019).

Lastly, research about positive affectivity reveals discrepant findings. Although most of the research cannot detect a significant association between positive affectivity and child BMI (Bergmeier et al., 2014), some research suggests that children with high positive affectivity tend to eat more, be more willing to eat and eat in the absence of hunger (Leung et al., 2014). In fact, recent research reveals that when positive affectivity is combined with other temperamental traits such as low inhibitory control, it may have detrimental effects on children's eating behaviors, making them more open to external stimuli and more impulsive at the same time (Zhou et al., 2019).

Further research suggests that when difficult temperament in children is combined by neglectful parenting behaviors, children are placed under higher risk for obesity (Wu et al., 2011). Thus, the findings indicate that a more integrative approach is needed to examine the effect of temperamental traits on childhood obesity. Examining temperamental characteristics of children in combined forms and in relation to parenting behaviors might facilitate a more comprehensive understanding of the subject.

\section{Conclusion}

Obesity is a widely increasing health problem, which is associated with detrimental effects on individuals' lives, both during the childhood and adulthood (Magarey et al., 2003; Reilly et al., 2003). Obesogenic eating behaviors are generally acquired during childhood years and affected by childhood experiences including parental behaviors and cognitions (Olvera-Ezzell et al., 1990; Scaglioni et al., 2008; Gahagan, 2012). Therefore, it is of great importance to determine early childhood precursors of obesity and develop intervention programs. Previous research has shown that parental child feeding behaviors, parenting styles, parental perceptions and child temperament are the most important precursors of obesity in early years. Specifically, restrictive feeding, authoritarian parenting style, inaccurate maternal cognitions and child temperamental traits such as negative affectivity and low inhibitory control were found to be associated with higher risk for obesity; while monitoring children's food intake and authoritative parenting style can play a protective role. Overall, longitudinal research generally confirmed these findings as well, however the amount of research that revealed conflictual or invalidating results cannot be underestimated.

The general discrepancy among the findings may arise from methodological variances among studies. For example, studies generally differ in their outcome variable. Some research regards child BMI as the outcome (e.g. Jansen et al., 2016) while some others measure dietary habits such as consumption of unhealthy foods or fruits/vegetables (e.g. Brown et al., 2008). Moreover, while some studies control for demographic variables such as parent BMI, parental education and child age (e.g. Rhee et al., 2006), some others do not (Rodgers et al., 2013). In fact, research shows different effects of parental feeding behaviors for different age groups of children (Campbell et al., 2010). Furthermore, lack of longitudinal data results in ambiguity in the findings, such that the direction of causation between the risk factors and child obesity remains unclear. Therefore, standardized methodology and further longitudinal research are needed in order to have a thorough understanding of early childhood obesity and its precursors. 